\title{
Participatory Multi-Criteria Decision Aid: Operationalizing an integrated assessment of ecosystem services
}

\author{
Johannes Langemeyer ${ }^{\mathrm{a}, \mathrm{b}}$, Ignacio Palomo ${ }^{\mathrm{c}, \mathrm{d}}$, Sergio Baraibar ${ }^{\mathrm{a}}$, Erik Gómez-Baggethun ${ }^{\mathrm{e}, \mathrm{f}}$
}

${ }^{a}$ Institute of Environmental Science and Technology (ICTA), Universitat Autònoma de Barcelona

(UAB), Carrer de les Columnes s/n, Campus de la UAB, 08193 Cerdanyola del Vallès, Spain

${ }^{\mathrm{b}}$ Hospital del Mar Medical Research Institute (IMIM), PRBB, Carrer Doctor Aiguader 88, 08003

Barcelona, Spain

${ }^{\mathrm{c}}$ Basque Centre for Climate Change, Edificio Sede, Campus EHU, Barrio Sarriena, s/n, 48940 Leioa, Vizcaya, Spain

${ }^{\mathrm{d}}$ Laboratorio de socio-ecosistemas, Universidad Autónoma de Madrid, C/Darwin 2, 28049, Cantoblanco, Madrid

${ }^{\mathrm{e}}$ Department of International Environment and Development Studies (Noragric), Norwegian University of Life Sciences (NMBU), P.O. Box 5003, Ås N-1432, Norway;

${ }^{\mathrm{f}}$ Norwegian Institute for Nature Research (NINA), Gaustadalleen 21, Oslo 0349, Norway

\begin{abstract}
Ongoing ecosystem alterations underscore the need for ecosystem service assessment to urgently enter policy-making. Participatory methods and a systematic inclusion of stakeholders are crucial yet underdeveloped cornerstones of environmental decision making. This study aims at conducting a transparent and legitimized integrated assessment of ecosystem services that rigorously involves stakeholder knowledge and values in environmental decision making. To this end, participatory multi-criteria decision aid was applied to the case of declining vineyard ecosystems surrounding the National Park of Doñana in south-west Spain. Data was gained by means of a survey $(\mathrm{n}=178)$, interviews $(\mathrm{n}=21)$, and three stakeholder workshops (each with $15-21$ participants). We found that stakeholder engagement improved all steps of decision making, including problem structuring, policy evaluation, and operationalization. Our results thereby reinforce two major arguments for adopting participatory methods in integrated ecosystem service assessments for environmental decision making: (1) the inclusion of stakeholders and their objectives adds legitimacy to decision making; (2) the integration of stakeholder knowledge provides important information for decision making.
\end{abstract}


Important note: This is the author's post-print version of a research paper that was accepted for publication in the journal Ecosystem Services (Elsevier). Therefore, it underwent full peer review but has not been through the copyediting, typesetting, pagination and proofreading process, which may lead to differences between this version and the published version: Langemeyer J., Baraibar S., Palomo I., Gómez-Baggethun E. (2018). Participatory Multi-Criteria Decision Aid: A way to operationalize ecosystem services. Ecosystem Services: 30 , Part A, 49-60. https://doi.org/10.1016/j.ecoser.2018.01.012

Key words: Ecosystem services stewardship $\bullet$ Integrated valuation $\bullet$ Multi-criteria evaluation • Doñana $\bullet$ Participatory decision making $\bullet$ Local ecological knowledge

\section{Key Messages:}

- Our study aimed at conducting an integrated assessment of ecosystem services using participatory multi-criteria decision aid.

- We found participatory multi-criteria decision aid to enhance transparency and legitimacy in environmental decision making.

- Integration of local ecological knowledge added meaningful information to ecosystem services assessments.

- Stakeholder involvement and empowerment showed to be key to enhance local ES stewardship. 
Important note: This is the author's post-print version of a research paper that was accepted for publication in the journal Ecosystem Services (Elsevier). Therefore, it underwent full peer review but has not been through the copyediting, typesetting, pagination and proofreading process, which may lead to differences between this version and the published version: Langemeyer J., Baraibar S., Palomo I., Gómez-Baggethun E. (2018). Participatory Multi-Criteria Decision Aid: A way to operationalize ecosystem services. Ecosystem Services: 30, Part A, 49-60. https://doi.org/10.1016/j.ecoser.2018.01.012

\section{$1 \quad 1$ Introduction}

2 Environmental policy-making and practice increasingly embraces the ecosystem services (ES) approach (Posner et al., 2016; Costanza et al., 2017; Dick et al., 2017; Saarikoski et al., 2017). MultiCriteria Decision Aid (MCDA) has been promoted as a methodological framework to include stakeholders in order to mitigate some of the major challenges for an integrated assessment of ES (IAES) (Uhde, 2015; Langemeyer et al., 2016; Saarikoski et al., 2016; Turner, 2016; Barton et al., 2017; Dunford et al., 2017). This includes: (1) evaluating policies considering and integrating ecological, social, and economic objectives (i.e., multiple values); (2) trading-off the multiple benefits social-ecological systems sustain for different people; and (3) informing environmental decision making to secure a resilient supply of ES ( $c f$. Jacobs et al., 2016).

The number of ES assessments across the world has increased rapidly over recent years, contributing to an improved understanding of the many ways in which human well-being depend on healthy ecosystems (e.g., Braat, 2014; Haase et al., 2014). However, decision making, especially at a local level, still largely lacks detailed information on the social-ecological linkages that sustain ES flows (Guerry et al., 2015) and, operational IAES approaches serving decision making still remain poorly developed (Gómez-Baggethun et al. 2016). Gradual "fine-tuning", mapping, and modeling is one way to improve ES assessments for local decision making; yet, drawing on Funtowicz \& Ravetz (1994) and Fish et al. (2016), it seems pertinent to additionally broaden decision making by integrating local stakeholder knowledge and objectives, especially if stakes are high for those affected by the decision (Fish et al., 2016). Barton et al. (2017) recommend an IAES to integrate multiple methods and diverse values, to be place-based, purpose-oriented and participatory. This is expected to enhance the transparency of an IAES, for example, in the way it deals with uncertainty (Ruckelshaus et al., 2015). Jacobs et al. (2016) highlighted the negotiation of conflicting societal needs and objectives as a key challenge for integrating ES values (i.e., diverse stakeholder preferences) into environmental decision making. Conflicting objectives underlying decision making require considerations of ethicalnormative arguments related to equity, social inclusion, intra- and inter-generational justice, and intrinsic values of nature (Wittmer et al., 2006).

MCDA can be described as a step-wise approach to structure and inform decision making (Saarikoski et al., 2016). Thus far, step-wise MCDA approaches for IAES commonly include: (i) definition of policy alternatives, (ii) definition of evaluation criteria, (iii) criteria scoring, (iv) criteria weighting, and (v) the application of an aggregation model (i.e., calculating a uniform quantitative index for comparing the policy alternatives) (Langemeyer et al., 2016). MCDA should have a strong theoretical 
Important note: This is the author's post-print version of a research paper that was accepted for publication in the journal Ecosystem Services (Elsevier). Therefore, it underwent full peer review but has not been through the copyediting, typesetting, pagination and proofreading process, which may lead to differences between this version and the published version: Langemeyer J., Baraibar S., Palomo I., Gómez-Baggethun E. (2018). Participatory Multi-Criteria Decision Aid: A way to operationalize ecosystem services. Ecosystem Services: 30, Part A, 49-60. https://doi.org/10.1016/j.ecoser.2018.01.012

capacity to accommodate stakeholder knowledge and conflicting objectives. Nevertheless, the inclusion of stakeholders in MCDA has generally been limited to single steps (Allain et al., 2017). The first two steps, which we summarize in this study as problem structuring, generally receive the least importance in MCDA from a participatory perspective (Langemeyer et al., 2016; Allain et al., 2017). A rare example for a participatory definition of policy alternatives is given by Fürst et al. (2013), who use stakeholder working groups in the development of landscape planning scenarios for Eastern Germany. Accordingly, only a few studies (e.g., Bryan \& Kandulu, 2011) rely on participatory approaches for the definition of evaluation criteria; in IAES this means the selection of ES is to be considered in an assessment. Usually, the evaluation criteria are introduced by researchers (Allain et al., 2017). Participatory approaches are more commonly used at the criteria performance scoring step, although often limited to a narrow circle of experts. A noteworthy example for using a wider participatory process for criteria performance scoring has been provided by Koschke et al. (2012). By revealing (expert and non-expert) stakeholder knowledge the authors determined the performance of less tangible ES (aesthetics, recreation, and ecotourism) under different policy alternatives and thereby manage to adjust for data-shortages on these ES. The most common step for stakeholder inclusion is the elicitation of criteria weights (Langemeyer et al., 2016). Objectives related to the supply of specific ES are thereby operationalized as criteria weights based on individual survey-based valuation or deliberative group valuation approaches (e.g., Karjalainen et al., 2013; Srdjevic et al., 2013; Zhang \& Lu, 2010; Zia et al., 2011).

Only exceptionally a more rigorous inclusion of stakeholders at multiple steps has been carried out (e.g., Cork \& Proctor, 2005). That means participation has not yet become an integrated part of decision-making processes supported by MCDA. A rigorous integration of stakeholder knowledge and objectives into environmental decision making as demanded by Fish et al. (2016) requires participatory approaches that stretch out across all common steps of MCDA. In addition, we follow Saarikoski et al. (2016) in the assumption that MCDA becomes most valuable when it serves to open up discussion. From this perspective, the application of an aggregation model is not the end-point of the assessment but the starting point for promoting reflection among stakeholders. Such an inclusive process can be referred to as participatory $M C D A$ and it is supposed to provide a clear structure for decision making that is comprehensible for stakeholders and facilitates utmost transparency (Wittmer et al., 2006). Participatory MCDA builds upon O’Neill's (2001) basic principle that effective and legitimate conflict resolution procedures in fuzzy environments require a high degree of transparency and stakeholder involvement, this is even more so if stakeholders are strongly affected by a decision (cf. Funtowicz and Ravetz 1993; Fish et al., 2016). The legitimacy of participatory MCDA thus relies 
Important note: This is the author's post-print version of a research paper that was accepted for publication in the journal Ecosystem Services (Elsevier). Therefore, it underwent full peer review but has not been through the copyediting, typesetting, pagination and proofreading process, which may lead to differences between this version and the published version: Langemeyer J., Baraibar S., Palomo I., Gómez-Baggethun E. (2018). Participatory Multi-Criteria Decision Aid: A way to operationalize ecosystem services. Ecosystem Services: 30, Part A, 49-60. https://doi.org/10.1016/j.ecoser.2018.01.012

on the representation and engagement of stakeholders at all steps of the decision making process. This makes participatory MCDA different from other MCDA approaches where complex mathematical evaluation models often diminish the transparency and comprehensiveness for non-expert stakeholders.

The goal of this study was to apply an IAES that rigorously integrates place-based stakeholder knowledge and objectives within a participatory MCDA process to enhance the transparency and legitimacy of the decision-making process it intends to inform. As a case study, we addressed traditional vineyards in the surroundings of the National Park of Doñana in south-west Spain, where land-use change is driving the decline of this agroecosystem and the ES it provides. Land-use change has been described as a main driver for the loss of ES from cultural landscapes (Foley et al., 2005; Lambin \& Meyfroidt, 2011), with cultural landscapes adjacent to protected areas being especially affected due to spill-over effects from conservation policies (Radeloff et al., 2010; Gimmi et al., 2011). Data was collected between 2014 and 2017. Initially a survey was conducted among 178 local residents (2014); in addition, we conducted two rounds of interviews with 10 and 11 stakeholders, 2014 and 2017 respectively, as well as three stakeholder workshops $(2015,2016,2017)$. The specific objectives of our study were (a) to assess ES provided by traditional vineyards as perceived by locals and to define policy alternatives that promote ES stewardship; (b) to evaluate alternative policies under consideration of multiple stakeholder objectives; and (c) to critically assess the use of participatory MCDA for IAES.

\section{Case Study}

The National Park of Doñana, created in 1969 and located at the mouth of the river Guadalquivir, can be considered one of the most emblematic wetlands in Europe and is internationally known for its outstanding biodiversity and related ecological and cultural values (Fernández et al., 2010). In response to spill-over effects in the form of an increasing degradation and agricultural intensification in the areas surrounding the National Park of Doñana and the Natural Park of Doñana, a $540 \mathrm{~km}^{2}$ "transition zone", defined as socially and economically impacted by the National Park, was created in 1989. Grapevine was traditionally the dominant crop in the transition zone (Zaller et al., 2015) and the century-long tradition of wine farming is highly adapted to Doñana's sensitive ecosystems. In addition to grape ( 8.3 tons per hectare), vinegar $(12.1 \mathrm{hl} / \mathrm{ha})$ and wine $(48.73 \mathrm{hl} / \mathrm{ha} /$ year $)$, traditional vineyards sustain diverse regulating ES, for example erosion control (Gaitan et al., 2016), and cultural ES, such as local identity, social cohesion and traditional ecological knowledge (Gómez-Baggethun et al. 2012). 
Important note: This is the author's post-print version of a research paper that was accepted for publication in the journal Ecosystem Services (Elsevier). Therefore, it underwent full peer review but has not been through the copyediting, typesetting, pagination and proofreading process, which may lead to differences between this version and the published version: Langemeyer J., Baraibar S., Palomo I., Gómez-Baggethun E. (2018). Participatory Multi-Criteria Decision Aid: A way to operationalize ecosystem services. Ecosystem Services: 30, Part A, 49-60. https://doi.org/10.1016/j.ecoser.2018.01.012

Wine farmers are thus important stewards who sustain these ES. Most wine farmers are smallholders and cultivate an average 1.5 ha of land. For most of them, wine production constitutes a supplementary income. Vineyards are mainly located in the municipalities of Bollullos Par del Condado (39\%), Rociana del Condado (16\%), and Almonte (12\%). The remaining 33\% are distributed across another 15 municipalities.

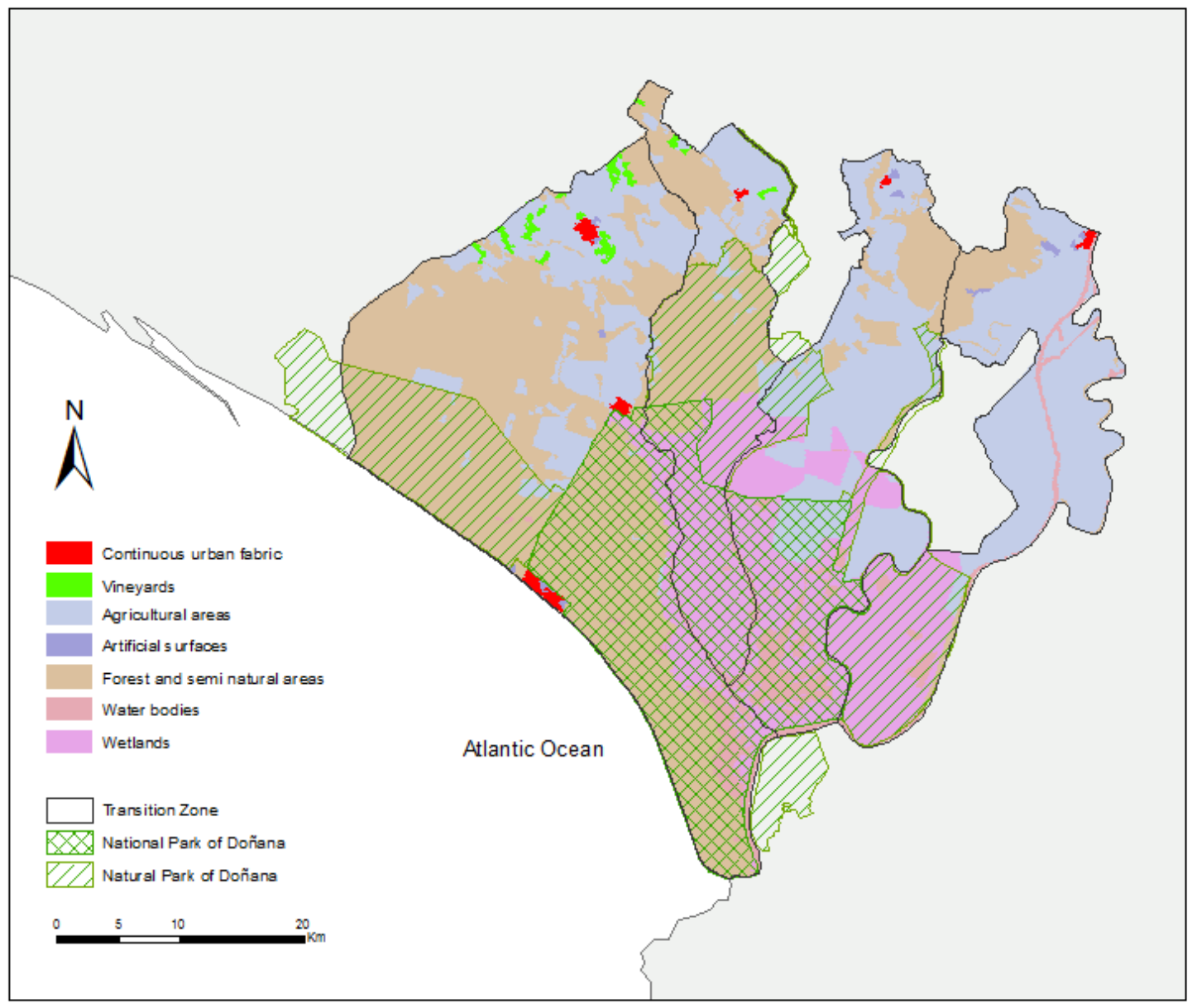

Figure 1. Land cover and protection status in the Doñana study area. Own elaboration based on the CORINE Land Cover inventory (http://land.copernicus.eu/pan-european/corine-land-cover/view) and spatial datasets provided by Spanish Centro Nacional de Información Geográfica.

The overarching challenge in our case study is the development, evaluation and consolidation of policies to maintain Doñana's traditional vineyards and the ES that they provide. Between 1983 and 
Important note: This is the author's post-print version of a research paper that was accepted for publication in the journal Ecosystem Services (Elsevier). Therefore, it underwent full peer review but has not been through the copyediting, typesetting, pagination and proofreading process, which may lead to differences between this version and the published version: Langemeyer J., Baraibar S., Palomo I., Gómez-Baggethun E. (2018). Participatory Multi-Criteria Decision Aid: A way to operationalize ecosystem services. Ecosystem Services: 30, Part A, 49-60. https://doi.org/10.1016/j.ecoser.2018.01.012

today the area of wine production in Doñana decreased from about $147 \mathrm{~km}^{2}$ to about $54 \mathrm{~km}^{2}$. In parallel, production declined from an average 90.000 tons/year in the 1980s to about 46.000 tons/year in the 1990s. A direct consequence was a reduction of employment in the sector and the loss of cultural identity and cultural heritage in a region where many local fests and celebrations are tied to the wine production cycle (Baraibar, 2015). In addition, a shift from wine production to fruit and berry plantations has caused an increase in (illegal) ground water consumption, leading to an important social-ecological conflict about the access to water for irrigation and the effects of aquifer depletion on temporal water bodies. The uprooting of vineyards and the subsequent transformation into nonpermanent cultivations is further causing a loss of arable soil and erosion; this erosion happening in the transition zone has been related with severe ecological impacts and degradation of important wetland ecosystems in the National Park of Doñana caused by increased sedimentation (GaitánCremaschi et al., 2017). As one of the most important drivers behind the loss of traditional vineyards, Gaitán-Cremaschi et al. (2017) identified subsidies by the European Union (EU) through the Common Agricultural Policy (CAP) for abandoning and uprooting vineyards in order to address an EU-wide overproduction of wine. This uprooting policy, which had been in place between 1988 and 1998, consisted in monetary incentives of up to $4327 €$ per uprooted hectare. Since the end of this policy, wine production stagnated and slightly revived since 2008 . However, this slight recovery was mainly related to the global financial crisis in 2007-2008, declining employment in urban areas, and a partial return to the countryside (Gaitan et al., 2017). Most likely, it does not constitute a turning point in the decline of traditional vineyards because other major drivers, such as the lack of generational turnover, stagnant grape prices and changes in the local lifestyle, continue to generate deteriorations for traditional wine producers and a loss in stewardship of ES (ibid.).

\section{Methodology}

A participatory MCDA approach was stretched out over three stakeholder workshops conducted in November, 2014, November, 2015, and January, 2017, respectively. It further included a face-to-face survey performed in fall of $2014(\mathrm{n}=172)$, and two rounds of semi-structured interviews; the first round was carried out with local stakeholders in October, 2014, $(\mathrm{n}=10)$ and the second round with workshop participants in April, 2016, $(\mathrm{n}=11)$. The participatory MCDA was structured into the following steps (Figure 2, adapted from Garmendia et al., 2010): Pre-assessment, Problem structuring, Evaluation, Reflection, and Post assessment. The Pre-Assessment constituted the identification of relevant stakeholders to participate in the study. The Problem Structuring comprised (a) the identification of relevant ES as evaluation criteria and (b) the creation of policy alternatives to 
Important note: This is the author's post-print version of a research paper that was accepted for publication in the journal Ecosystem Services (Elsevier). Therefore, it underwent full peer review but has not been through the copyediting, typesetting, pagination and proofreading process, which may lead to differences between this version and the published version: Langemeyer J., Baraibar S., Palomo I., Gómez-Baggethun E. (2018). Participatory Multi-Criteria Decision Aid: A way to operationalize ecosystem services. Ecosystem Services: 30 , Part A, 49-60. https://doi.org/10.1016/j.ecoser.2018.01.012

diminish ES losses. The Evaluation involved (a) the criteria performance scoring (based on the stakeholders' perception of criteria performance under each policy alternative), (b) elicitation of criteria weights (based on the relative importance of criteria for the stakeholders), as well as (c) the application of a mathematical aggregation model (calculating the weighed scores to obtain a uniform quantitative index for comparing the policy alternatives). The Reflection involved a final discussion on the evaluation of policy alternatives and, the Post-Assessment, a quality control of the entire participatory MCDA process.

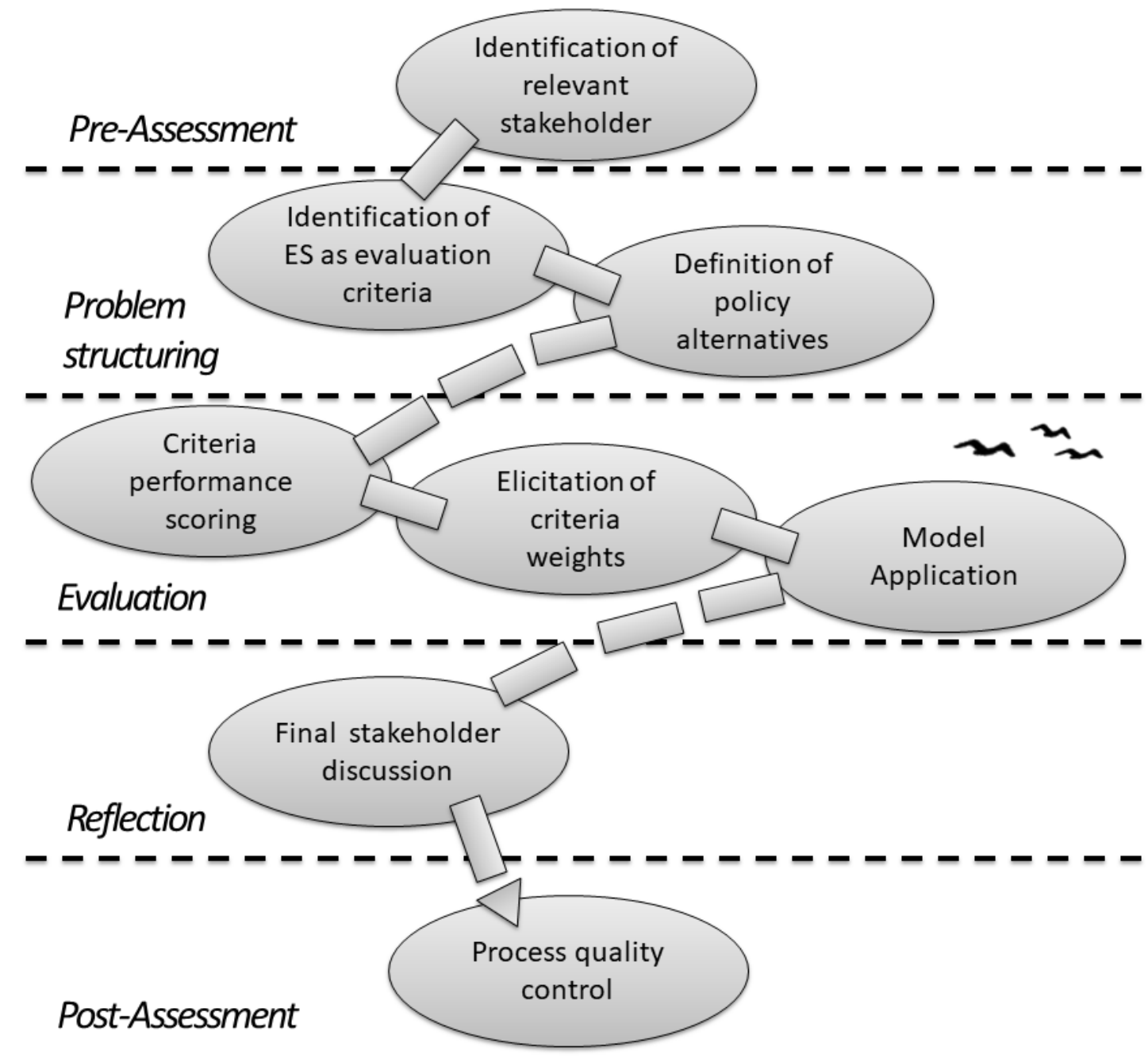

Figure 2. The process of participatory multi-criteria decision aid used for an IAES to maintain ecosystem services from the traditional vineyards of Doñana, Spain 
Important note: This is the author's post-print version of a research paper that was accepted for publication in the journal Ecosystem Services (Elsevier). Therefore, it underwent full peer review but has not been through the copyediting, typesetting, pagination and proofreading process, which may lead to differences between this version and the published version: Langemeyer J., Baraibar S., Palomo I., Gómez-Baggethun E. (2018). Participatory Multi-Criteria Decision Aid: A way to operationalize ecosystem services. Ecosystem Services: 30, Part A, 49-60. https://doi.org/10.1016/j.ecoser.2018.01.012

\subsection{Pre-Assessment of stakeholders to participate}

For the purpose of our study, an advisory board ( $c f$. Dick et al, forthcoming) comprising relevant local and regional stakeholders was created. Stakeholders were defined as individuals, groups, and (public) institutions whose realms were negatively affected by the changing land uses, including representatives of environmental NGOs and/or those whose decisions can influence the provision of ES from traditional vineyards. An interdisciplinary group of researchers (including the authors of this study) with several years of working experiences in the study area contacted the local conservation and development organizations Fundación Doñana 21 (FD21) to be advised and assisted in the selection of stakeholders. FD21 was founded with the objective to support the integration of ecological and socio-economic objectives in the transition zone surrounding Doñana's protected areas and holds a mandate from the Andalusian government to mediate where these objectives conflict with each other. FD21 had already worked for several years toward the protection of traditional vineyards and was the major force behind bringing the topic into our research agenda. Assisted by the FD21, an initial list of stakeholders associated with traditional vineyards in Doñana was developed. This list was thereafter enlarged using a snowball technique, whereby initially identified stakeholders are asked to name additional, relevant stakeholders (Bernard, 2005). The main stakeholder group that is both, affected by the decision at stake and influencing land uses by their management practices comprised traditional winegrowers (about 3180). The vast majority of these vineyard farmers (92\%) are organized in production and commercialization cooperatives, and their elected representatives and technical advisors formed the main body of the advisory board. The focus on traditional wine farmers was motivated by their critical role as stewards of ES. Other farmers in the area, for example strawberry producers, adopt more industrial management practices that are assumed not to be adapted to the ecosystem and rather harmful to ES provision. There is an important social conflict going on between producers of ecologically non-adapted crops and the National Park administration (Turkelboom et al., 2017); and we assumed that the resources available for this study would not allow addressing this major conflict in an appropriate manner. A second group of stakeholders was formed by representatives of private wine producing companies with larger vineyards. In addition, representatives of SEO Birdlife, an environmental NGO concerned with biodiversity protection as well as representatives from the D.O. Condado de Huelva (regional wine producers' association), joined the advisory board. Due to their influence on decision making, the municipalities Bollullos Par del Condado, Rociana del Condado, and Almonte were represented by managers from the agricultural and tourism departments. The National Park of Doñana was represented by Environmental Department of the regional Government of Andalusia (Consejo de Medioambiente, Junta de Andalucia) that is 
Important note: This is the author's post-print version of a research paper that was accepted for publication in the journal Ecosystem Services (Elsevier). Therefore, it underwent full peer review but has not been through the copyediting, typesetting, pagination and proofreading process, which may lead to differences between this version and the published version: Langemeyer J., Baraibar S., Palomo I., Gómez-Baggethun E. (2018). Participatory Multi-Criteria Decision Aid: A way to operationalize ecosystem services. Ecosystem Services: 30 , Part A, 49-60. https://doi.org/10.1016/j.ecoser.2018.01.012

181

182

183

responsible for the park management both as a major decision-making institution as well as an institution being affected by decisions. The agricultural department from the Andalusian government could not be convinced to join the process, despite its important influence on land-use decision making.

\subsection{Problem structuring}

Problem structuring was addressed during the first round of semi-structured interviews and the first participatory workshop.

\subsubsection{Creation of policy alternatives}

The definition of policy alternatives was based on ten semi-structured interviews $(n=10)$ with local stakeholders, including two winegrowers, two wine producers, the owner of a winery, one wine tourism entrepreneur, two local elders, one municipal manager, and one manager of the National Park of Doñana. One section of the interview was specifically designed to acquire proposals of potential policies to halt the loss of traditional vineyards and related ES. The different proposals derived from the interviews were presented and further developed during the first participatory workshop with the advisory board $(n=14)$. The full list of workshop participants and the workshop program is given in Annex A. The workshop discussions led to the definition and final selection of eight policy alternatives (see 4.1 for the list of policy alternatives).

\subsubsection{Definition of evaluation criteria}

The semi-structured interviews described before were also used to identify the most important ES that traditional vineyards provide as perceived by local stakeholders. To this end, one interview section consisted of a "free-listing" of benefits that people relate with traditional vineyards. The coding of responses was guided by established ES classifications MA (2005), TEEB (2010), and CICES (Haines-Young \& Potschin, 2013). The ES identified through the coding were then prioritized by means of a survey $(\mathrm{n}=172)$. The survey was conducted among randomly met individuals in the municipalities of Bollullos Par del Condado, Almonte, and Rociana del Condado. Survey participants were asked to express the level of importance of ES on a Likert scale, distinguishing importance levels as "high", "substantial", "small”, and "negligible". Likert scale rankings are an established tool for the social-cultural valuation of ES (e.g., Camps-Calvet et al. 2016; Soy-Massoni et al. 2016). Next, survey participants were asked to state the perceived trend of each of the ES over the last 20 years; these responses were standardized into declining, stable, enhancing, and not sure. The final list of evaluation criteria encompassed all ES identified as "most important" by at least $40 \%$ of the survey respondents (Figure 3). 
Important note: This is the author's post-print version of a research paper that was accepted for publication in the journal Ecosystem Services (Elsevier). Therefore, it underwent full peer review but has not been through the copyediting, typesetting, pagination and proofreading process, which may lead to differences between this version and the published version: Langemeyer J., Baraibar S., Palomo I., Gómez-Baggethun E. (2018). Participatory Multi-Criteria Decision Aid: A way to operationalize ecosystem services. Ecosystem Services: 30, Part A, 49-60. https://doi.org/10.1016/j.ecoser.2018.01.012

213 When ES provision based evaluation criteria were discussed with the FD21, an additional list of 214 evaluation criteria was proposed and brought into discussion during the second stakeholder workshop. Participants of this workshop then agreed on five additional criteria that were supposed to describe the social and economic impact of policy alternatives on the one hand and policy constraints in the form of implementation costs on the other hand (Figure 3).

\subsection{Evaluation of policy alternatives}

The policy evaluation included criteria performance scoring and criteria importance weighing as well as the application of a mathematical aggregation model. The criteria scoring and weighting were both conducted in participatory manner during the second advisory board meeting among 20 participants (see Annex B).

\subsubsection{Criteria performance scoring}

224 For the participatory scoring exercise, participants were split into four groups, whereby stakeholders from different domains, such as wine farmers and NGO representatives, were heterogeneously mixed across groups. Split-up groups were facilitated by a research team member or by an FD21 expert. Each group discussed and scored each criterion for each of the eight policy alternatives and for the status quo. The final score for each criterion was derived as the average of the scores provided by each of the four stakeholder groups (see Table 2). Criteria related to policy objectives (see Fig. 3) were scored as worse (numeric score: 0.000), approximately equal (0.333), better (0.666), and much better (1.000). Criteria related to policy constraints were scored as low (numeric score: 1.000), moderate (0.666), high (0.333), and very high (0.000).

\subsubsection{Elicitation of criteria weights}

234 The elicitation of criteria weights was conducted as an individual valuation exercise by 18 workshop participants. The weighting was carried out on a five-point Likert scale, each scale attached to a linguistic variable (this is a common approach in MCDA, see Allain et al., 2017). The answers were then normalized into numerical weighting factors between 0 and 1 . The linguistic variable no importance renders a weighting factor of 0.00 , low importance a weighting factor of 0.25 , medium importance of 0.50 , high importance of 0.75 , and very high importance of 1.00 . The final weights used in the evaluation were established as average values across all workshop participants (see Figure 4).

\subsubsection{Model application}

242 The application of an aggregation model followed the objective to rank the policy alternative regarding their suitability in meeting the evaluation criteria. For this purpose, we used a weighted 
Important note: This is the author's post-print version of a research paper that was accepted for publication in the journal Ecosystem Services (Elsevier). Therefore, it underwent full peer review but has not been through the copyediting, typesetting, pagination and proofreading process, which may lead to differences between this version and the published version: Langemeyer J., Baraibar S., Palomo I., Gómez-Baggethun E. (2018). Participatory Multi-Criteria Decision Aid: A way to operationalize ecosystem services. Ecosystem Services: 30 , Part A, 49-60. https://doi.org/10.1016/j.ecoser.2018.01.012

244 linear aggregation (WLA) model - a model that is commonly used in MCDA (Langemeyer et al., 245 2016; Allain et al., 2017). Thereby, the alternative ranking is determined by the sum of the weighted 246 criteria performance scores across all criteria. We applied both equal weights (weighting factor $=1$ ) and average stakeholder weights (see Table 3) elicited during the second participatory workshop.

\subsection{Reflection}

The reflection included a final discussion of evaluation results. This discussion followed recommendations by Saarikoski et al. (2016) to use the potential of MCDA in ranking policy alternatives as an input to "open up discussion" rather than to close it down. The goal of this exercise was an additional critical reflection on the evaluation of policy alternatives and a feasibility-check for the implementation of alternatives. Therefore, evaluation results were presented to 16 participants of a third stakeholder workshop, which took place in January, 2017 (see Annex C). For the discussion, stakeholders were divided into four heterogeneously split-up groups each either facilitated by a researcher or an FD21 expert, who also kept notes of the discussion results. Within each split-up group, two out of the eight policy alternatives were discussed with regard to potential facilitators, i.e., crucial stakeholders and barriers for their implementation. Discussions in the split-up groups were followed by a group discussion including all workshop participants. Results constitute a summary of the main discussion points based on the facilitators' notes.

\subsection{Post-assessment for quality control}

Finally, and in order to control for the quality of the participatory process, we conducted a second round of interviews. The interviews were centrally designed for all 27 case studies of the European Union-funded research project OpenNESS (www.openness-project.eu). For a detailed description of the interview structure and further details on the results see Dick et al. (forthcoming): Case study 19 (DONN). The selection of interview partners was proposed by FD21 and restricted to stakeholders who had participated in the stakeholder workshops. Eleven interviews were conducted in April 2016; nine as face-to-face interviews and two in written form. Following Fish et al. (2016), results from the interviews were structured around three major arguments for stakeholder involvement in environmental decision making: normative-based arguments, process-based arguments, and outcomebased arguments. 
Important note: This is the author's post-print version of a research paper that was accepted for publication in the journal Ecosystem Services (Elsevier). Therefore, it underwent full peer review but has not been through the copyediting, typesetting, pagination and proofreading process, which may lead to differences between this version and the published version: Langemeyer J., Baraibar S., Palomo I., Gómez-Baggethun E. (2018). Participatory Multi-Criteria Decision Aid: A way to operationalize ecosystem services. Ecosystem Services: 30, Part A, 49-60. https://doi.org/10.1016/j.ecoser.2018.01.012

\section{RESULTS}

\section{4.1 Evaluation criteria and policy alternatives}

274 Our study identified 17 ES provided by the traditional vineyards of Doñana (Table 1). Most of the 275 identified ES broadly correspond to internationally established ES classifications (MA, 2005; TEEB, 276 2010; Haines-Young \& Potschin, 2013). Others capture flows of benefits that are more specific for the 277 traditional vineyards of Doñana, such as maintenance of traditional ecological knowledge. The six 278 most important ES identified by local residents and selected as evaluation criteria reflect the close 279 cultural ties between the local population and wine production and include: (1) food production (grapes, wine, vinegar), (2) sedimentation and erosion control, (3) provision of ecological corridors for biodiversity, (4) maintenance of cultural identity, (5) landscape aesthetics, and (6) wine tourism. All six criteria were deemed substantial or highly important (based on the Likert scale rankings), and, with the exception of wine tourism, all six were assumed to have declined over the past 20 years.

Following stakeholder requests, the list of evaluation criteria was complemented by employment and economic impact on wine sales to evaluate the socio-economic impact of policies, as well as time use, administrative difficulty, and monetary costs to assess the implementation costs of different policies. This produced a total of 11 evaluation criteria that were subsequently scored and weighed by the workshop participants (Fig. 3). 
Important note: This is the author's post-print version of a research paper that was accepted for publication in the journal Ecosystem Services (Elsevier). Therefore, it underwent full peer review but has not been through the copyediting, typesetting, pagination and proofreading process, which may lead to differences between this version and the published version: Langemeyer J., Baraibar S., Palomo I., Gómez-Baggethun E. (2018). Participatory Multi-Criteria Decision Aid: A way to operationalize ecosystem services. Ecosystem Services: 30, Part A, 49-60. https://doi.org/10.1016/j.ecoser.2018.01.012

Table 1. Perceived importance of ES from Doñana's traditional vineyards and their trends over the past 20 years. Importance of ES derived from Likert scale ranking $(1=$ negligible, $2=$ small, $3=$ substantial, $4=$ high) and stated perception of ES trend, both based on a survey among local citizens $(N=172)$.

\begin{tabular}{|c|c|c|c|c|c|c|c|c|}
\hline \multirow{2}{*}{ Ecosystem services } & \multicolumn{3}{|c|}{ Likert scale ranking } & \multicolumn{5}{|c|}{ Trend } \\
\hline & Selected & Mean & $S D$ & Decline & Stable & Increase & Not sure & Overall \\
\hline $\begin{array}{l}\text { Food production (grapes, } \\
\text { wine, vinegar) }\end{array}$ & $63 \%$ & 3,71 & $(1,59)$ & $57.8 \%$ & $17.4 \%$ & $14.7 \%$ & $10.1 \%$ & $\searrow$ \\
\hline $\begin{array}{l}\text { Maintenance of cultural } \\
\text { identity }\end{array}$ & $62 \%$ & 3,28 & $(1,36)$ & $46.7 \%$ & $34.6 \%$ & $10.3 \%$ & $8.4 \%$ & $\searrow / \leftrightarrow$ \\
\hline $\begin{array}{l}\text { Provision of ecological } \\
\text { corridors for biodiversity }\end{array}$ & $55 \%$ & 3,45 & $(1,35)$ & $68.4 \%$ & $10.5 \%$ & $7.3 \%$ & $13.7 \%$ & $\searrow$ \\
\hline $\begin{array}{l}\text { Sedimentation and erosion } \\
\text { control }\end{array}$ & $55 \%$ & 3,25 & $(1,29)$ & $70.5 \%$ & $7.4 \%$ & $4.2 \%$ & $17.9 \%$ & $\searrow$ \\
\hline Landscape aesthetics & $44 \%$ & 2,65 & $(1,36)$ & $54.0 \%$ & $25.0 \%$ & $3.9 \%$ & $17.1 \%$ & $\searrow$ \\
\hline Wine tourism & $42 \%$ & 2,68 & $(1,33)$ & $4.1 \%$ & $13.7 \%$ & $82.5 \%$ & $12.7 \%$ & $\pi$ \\
\hline Water regulation & $35 \%$ & 2,80 & $(1,24)$ & $41.0 \%$ & $37.7 \%$ & $8.2 \%$ & $13.1 \%$ & $\searrow / \leftrightarrow$ \\
\hline $\begin{array}{l}\text { Village fetes associated with } \\
\text { vineyards/wine production }{ }^{1}\end{array}$ & $29 \%$ & 2,60 & $(1,26)$ & $28.0 \%$ & $56.0 \%$ & $6.0 \%$ & $10.0 \%$ & $\leftrightarrow$ \\
\hline Cohesive and social unifier ${ }^{2}$ & $23 \%$ & 2,61 & $(1,20)$ & $66.7 \%$ & $15.4 \%$ & $5.1 \%$ & $12.8 \%$ & $\searrow$ \\
\hline $\begin{array}{l}\text { Artistic manifestations } \\
\text { associated with } \\
\text { vineyards/wine production }\end{array}$ & $21 \%$ & 2,36 & $(1,26)$ & $25.0 \%$ & $30.6 \%$ & $19.4 \%$ & $25.0 \%$ & $\leftrightarrow$ \\
\hline Climate regulation & $15 \%$ & 2,69 & $(1,34)$ & $42.3 \%$ & $34.6 \%$ & $0.0 \%$ & $23.1 \%$ & $\searrow / \leftrightarrow$ \\
\hline $\begin{array}{l}\text { Maintenance of traditional } \\
\text { ecological knowledge }\end{array}$ & $13 \%$ & 2,59 & $(1,46)$ & $86.5 \%$ & $4.5 \%$ & $4.5 \%$ & $4.5 \%$ & $\searrow$ \\
\hline $\begin{array}{l}\text { Maintenance of traditional } \\
\text { farming techniques }\end{array}$ & $11 \%$ & 2,84 & $(1,06)$ & $94.7 \%$ & $0.0 \%$ & $0.0 \%$ & $5.3 \%$ & $\searrow$ \\
\hline Biomass production & $9 \%$ & 2,31 & $(1,49)$ & $56.3 \%$ & $18.7 \%$ & $0.0 \%$ & $25.0 \%$ & $\searrow$ \\
\hline Agro-biodiversity & $8 \%$ & 2,92 & $(1,32)$ & $21.4 \%$ & $42.9 \%$ & $21.4 \%$ & $14.3 \%$ & $\leftrightarrow$ \\
\hline Resistance to plagues & $8 \%$ & 2,14 & $(1,09)$ & $21.4 \%$ & $71.4 \%$ & $0.0 \%$ & $7.2 \%$ & $\leftrightarrow$ \\
\hline Firewall & $5 \%$ & 1,75 & $(1,03)$ & $12.5 \%$ & $50.0 \%$ & $0.0 \%$ & $37.5 \%$ & $\leftrightarrow$ \\
\hline \multicolumn{9}{|c|}{$\begin{array}{l}{ }^{3} \text { The close cultural link between local people and wine production is manifested in the work by local artists, such as poets, } \\
\text { painters, and musicians. } \\
\text { Traditional wine farmers (and producers) are assumed to hold extensive knowledge on the local ecosystem system and its } \\
\text { interplay for instance with climatic phenomena. }\end{array}$} \\
\hline
\end{tabular}


Important note: This is the author's post-print version of a research paper that was accepted for publication in the journal Ecosystem Services (Elsevier). Therefore, it underwent full peer review but has not been through the copyediting, typesetting, pagination and proofreading process, which may lead to differences between this version and the published version: Langemeyer J., Baraibar S., Palomo I., Gómez-Baggethun E. (2018). Participatory Multi-Criteria Decision Aid: A way to operationalize ecosystem services. Ecosystem Services: 30 , Part A, 49-60. https://doi.org/10.1016/j.ecoser.2018.01.012

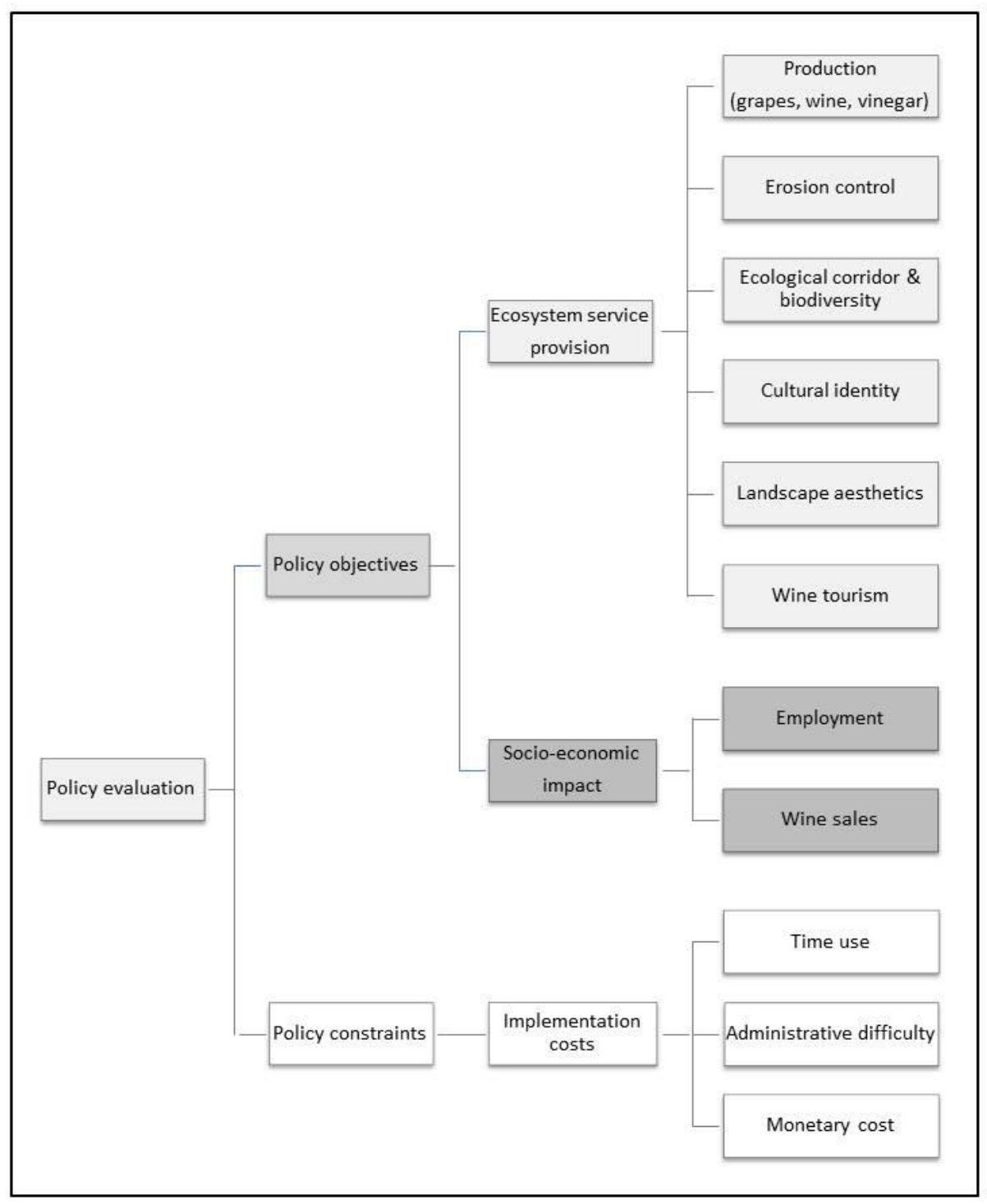

Figure 3. Evaluation criteria used in the participatory MCDA in decision making to maintain Doñana's traditional vineyards and ES. Criteria related to the ecosystem services provision derived from a survey of 172 local inhabitants; criteria related to the socio-economic impact and implementation costs defined during a stakeholder workshop. 
Important note: This is the author's post-print version of a research paper that was accepted for publication in the journal Ecosystem Services (Elsevier). Therefore, it underwent full peer review but has not been through the copyediting, typesetting, pagination and proofreading process, which may lead to differences between this version and the published version: Langemeyer J., Baraibar S., Palomo I., Gómez-Baggethun E. (2018). Participatory Multi-Criteria Decision Aid: A way to operationalize ecosystem services. Ecosystem Services: 30, Part A, 49-60. https://doi.org/10.1016/j.ecoser.2018.01.012

Based on the survey and the first stakeholder workshop, eight policy alternatives were established in support of Doñana's traditional vineyards and to sustain the ES they provide. These policy alternatives include:

A. The promotion of marketing strategies for traditional vineyards' products; this measure was initially thought to be implemented by the National Ministry of Agriculture, yet later in the participatory process it was also discussed as a measure that could be implemented at the local level.

B. Ecolabelling consists in the creation of a certification scheme based on the denomination of origin, in this case, associated to the Natural Park of Doñana, and by a set of ecological criteria that a certified wine product would need to comply with.

C. The promotion of wine tourism was thought of as a measure to be implemented by public (local) entities.

D. The implementation of payments for the provision of ES includes the creation of monetary incentives for viticulturists; during the participatory process it could neither be specified who would need to pay for these ES nor as to which ES would enter the scheme.

E. The promotion of traditional vineyards for the European Union's Common Agricultural Policy (CAP) subsidies was meant to be implemented within in the framework of the Andalusian rural development plan (2014-2020).

F. The promotion to declare Doñana's traditional vineyards as UNESCO Cultural World Heritage sites was encouraged by the tentative listing of La Rioja and Rioja Alavesa as Cultural World Heritage sites (http://whc.unesco.org/en/tentativelists/5793/).

G. Awareness generation on ES stewardship provided by traditional vineyards includes educational campaigns at different levels, such as at public administrations, among local population, and in the wine-producing sector itself.

F. The tax reduction for wine farmers involves property related taxes or product related taxes and was meant as policy to be implemented at the national level.

In addition to these eight policy alternatives, we introduced the status quo that means no additional action to be evaluated as the ninth alternative, alongside the others. 
Important note: This is the author's post-print version of a research paper that was accepted for publication in the journal Ecosystem Services (Elsevier). Therefore, it underwent full peer review but has not been through the copyediting, typesetting, pagination and proofreading process, which may lead to differences between this version and the published version: Langemeyer J., Baraibar S., Palomo I., Gómez-Baggethun E. (2018). Participatory Multi-Criteria Decision Aid: A way to operationalize ecosystem services. Ecosystem Services: 30, Part A, 49-60. https://doi.org/10.1016/j.ecoser.2018.01.012

\subsection{Evaluation of policy alternatives}

319 The evaluation included the comparison of eight policy alternatives across 11 evaluation criteria (Fig 320 3). By means of participatory criteria performance scoring, the impacts of the policy alternatives and 321 the status quo on the criteria were estimated (Table 2). Possibilities for improvement were especially 322 seen for wine tourism, to lower the extents for the maintenance of cultural identity and for wine sales. 323 Food production (grapes, wine, vinegar) is assumed to have lower elasticity, expressed in criteria scores between 0.33 and 0.58 ; this means this criterion has a lower sensitivity to changes induced by the proposed policy alternatives.

Table 2. Impact matrix for the evaluation of policy alternatives to maintain Doñana's traditional vineyards

Scorings derived through a participatory scoring exercise. Individual criterion scores represent the average score across four split-up groups. Policy objectives criteria scored as follows: worse (0.000), approximately equal (0.333), better (0.666), and much better (1.000). Policy constraints criteria scored as low (1.000), moderate (0.666), high (0.333), and very high (0.000).

\begin{tabular}{|c|c|c|c|c|c|c|c|c|c|c|c|}
\hline \multirow[b]{2}{*}{ Policy Alternatives } & \multicolumn{8}{|c|}{ Policy objectives criteria } & \multicolumn{3}{|c|}{ Policy constraints criteria } \\
\hline & 胥 & 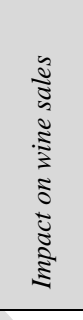 & 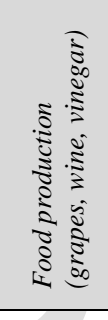 & 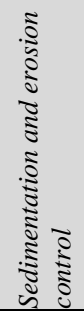 & 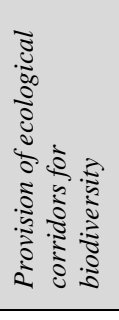 & 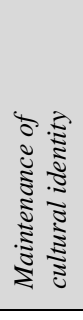 & 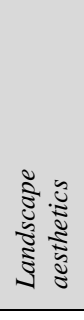 & 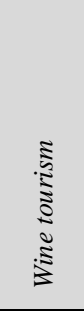 & $\begin{array}{l}\check{\Xi} \\
\cong \\
\Xi\end{array}$ & 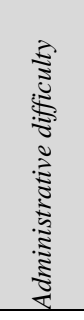 & 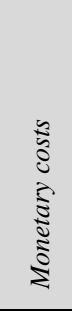 \\
\hline $\begin{array}{l}\text { A. Promotion of marketing } \\
\text { strategies }\end{array}$ & 0.83 & 0.92 & 0.50 & 0.58 & 0.58 & 0.92 & 0.58 & 1.00 & 0.67 & 0.58 & 0.25 \\
\hline B. Ecolabelling & 0.67 & 0.92 & 0.33 & 0.58 & 0.58 & 0.75 & 0.58 & 0.83 & 0.67 & 0.58 & 0.67 \\
\hline $\begin{array}{l}\text { C. Promotion of wine } \\
\text { tourism }\end{array}$ & 0.83 & 0.75 & 0.42 & 0.42 & 0.50 & 0.92 & 0.83 & 1.00 & 0.58 & 0.58 & 0.33 \\
\hline $\begin{array}{l}\text { D. Payments for } \\
\text { ecosystem services }\end{array}$ & 0.67 & 0.58 & 0.58 & 0.67 & 0.75 & 0.67 & 0.67 & 0.83 & 0.33 & 0.42 & 0.33 \\
\hline $\begin{array}{l}\text { E. UNESCO Cultural } \\
\text { World Heritage }\end{array}$ & 0.67 & 0.75 & 0.42 & 0.50 & 0.58 & 0.92 & 0.67 & 1.00 & 0.17 & 0.08 & 0.50 \\
\hline $\begin{array}{l}\text { F. Awareness raising for } \\
\text { ecosystem services } \\
\text { stewardship }\end{array}$ & 0.42 & 0.67 & 0.42 & 0.50 & 0.50 & 0.83 & 0.75 & 0.83 & 0.33 & 0.17 & 0.75 \\
\hline $\begin{array}{l}\text { G. Common Agricultural } \\
\text { Policy }(C A P) \text { subsidies }\end{array}$ & 0.67 & 0.33 & 0.58 & 0.58 & 0.58 & 0.50 & 0.67 & 0.50 & 1.00 & 0.67 & 0.25 \\
\hline
\end{tabular}


Important note: This is the author's post-print version of a research paper that was accepted for publication in the journal Ecosystem Services (Elsevier). Therefore, it underwent full peer review but has not been through the copyediting, typesetting, pagination and proofreading process, which may lead to differences between this version and the published version: Langemeyer J., Baraibar S., Palomo I., Gómez-Baggethun E. (2018). Participatory Multi-Criteria Decision Aid: A way to operationalize ecosystem services. Ecosystem Services: 30 , Part A, 49-60. https://doi.org/10.1016/j.ecoser.2018.01.012

H. Tax reduction for wine farmers

0.58

$0.42 \quad 0.42$

0.33

0.33

0.42

0.42

0.33

1.00

1.00

0.08

Status Quo

0.0

0.0

0.0

0.0

0.0

0.0

0.0

0.00

1.00

1.00

1.00 
Important note: This is the author's post-print version of a research paper that was accepted for publication in the journal Ecosystem Services (Elsevier). Therefore, it underwent full peer review but has not been through the copyediting, typesetting, pagination and proofreading process, which may lead to differences between this version and the published version: Langemeyer J., Baraibar S., Palomo I., Gómez-Baggethun E. (2018). Participatory Multi-Criteria Decision Aid: A way to operationalize ecosystem services. Ecosystem Services: 30, Part A, 49-60. https://doi.org/10.1016/j.ecoser.2018.01.012

327 The weighting of criteria conducted through a stakeholder survey indicates a particular importance of 328 the socio-economic criteria employment and wine sales (Fig. 4). From the six ES that had been weighted, in average, only wine tourism was given the same importance $(\varnothing=0.81)$. Fairly low standard deviations of weights assigned to the criteria indicate a general consensus among individual stakeholders about the importance of these criteria. Stakeholders especially agreed on the high importance of wine tourism $(\sigma=0.11)$. Lower consensus was seen regarding the importance of the provision of ecological corridors for biodiversity $(\sigma=0.19)$ and the maintenance of cultural identity $(\sigma=0.20)$.

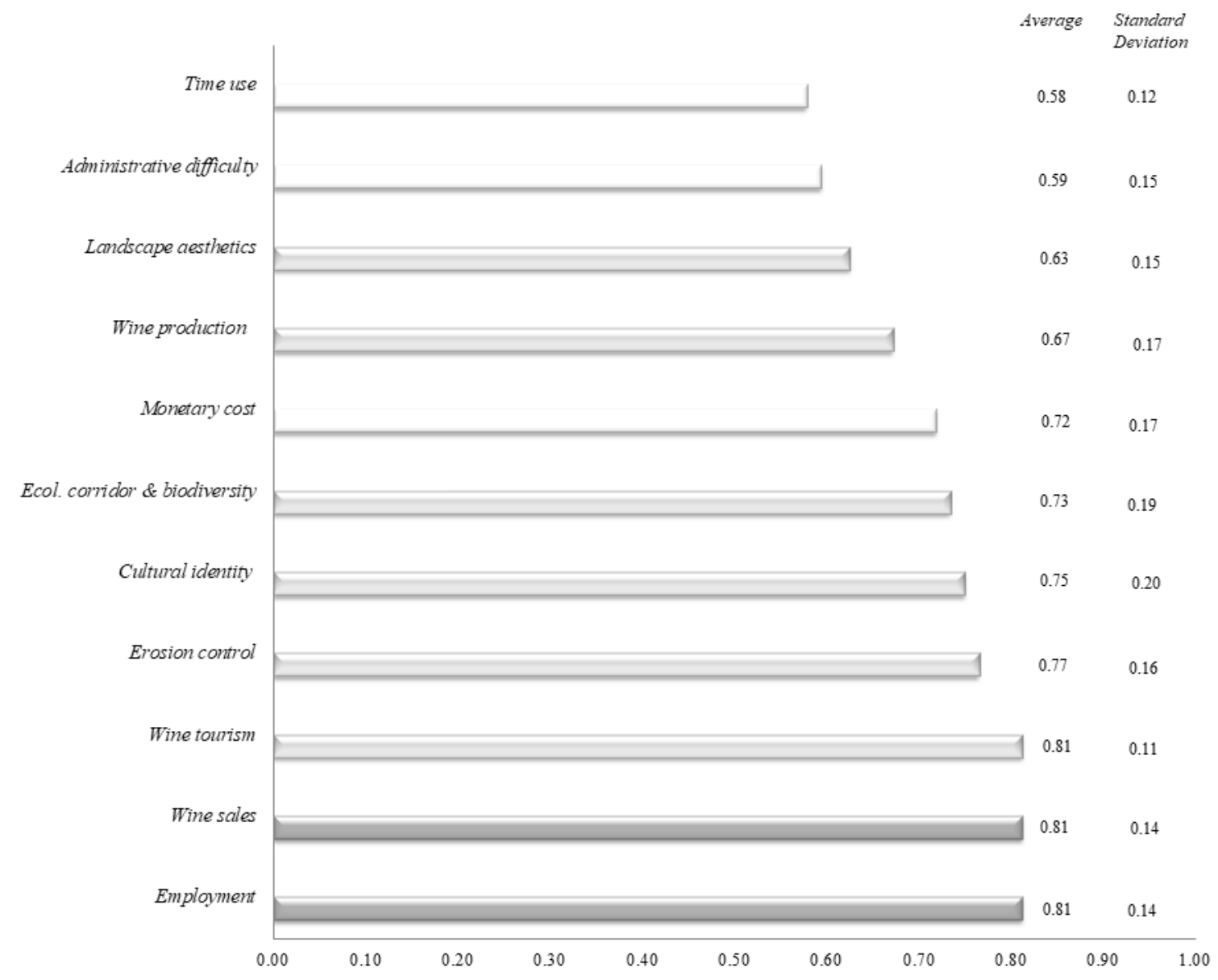

Figure 4: Weights assigned to evaluation criteria in the case of Doñana's traditional vineyards Weights have been assigned by 18 stakeholders using Likert scale rankings embedded in an individual survey (conducted during a stakeholder workshop). 
Important note: This is the author's post-print version of a research paper that was accepted for publication in the journal Ecosystem Services (Elsevier). Therefore, it underwent full peer review but has not been through the copyediting, typesetting, pagination and proofreading process, which may lead to differences between this version and the published version: Langemeyer J., Baraibar S., Palomo I., Gómez-Baggethun E. (2018). Participatory Multi-Criteria Decision Aid: A way to operationalize ecosystem services. Ecosystem Services: 30, Part A, 49-60. https://doi.org/10.1016/j.ecoser.2018.01.012

Through the application of the WLA model, two rankings of the policy alternatives have been created (Table 3). Ranking I results from an application of equal weights (weighting factor $=1$ ), which means it is directly derived from the scores of the impact matrix (Table 2). Ranking II is based on the same scores under consideration of the specific weights assigned by stakeholders to each evaluation criterion (Annex D: Impact matrix under consideration of stakeholder weighting). Both rankings are roughly consistent, for instance in the first position in which the policy alternative A. Promotion of marketing strategies is placed and in the last position where the Status Quo is located. The application of stakeholder weights showed only small differences compared to Ranking I. The change in alternatives B. Ecolabelling and C. Promotion of wine tourism on the second and the third positions of the ranking is almost negligible due to the extremely small differences in the scorings. A larger difference can be observed in alternative G. Common Agricultural Policy (CAP) subsidies. This alternative ranked fifth in the equal weights Ranking I but only seventh under consideration of stakeholder weights in Ranking II.

Table 3. Evaluation of policies to maintain Doñana's traditional vineyards and related ES.

The evaluation relies on the assumed impact of policy alternatives on 11 evaluation criteria; these impacts have been determined during a participatory workshop on a scale between 0 and 1 . The final ranking is determined by the sum of weighted criteria impacts. Ranking I is based on equal weights (weighting factor $=1$ ) across all criteria (Annex D). Ranking II is based on weights elicited during a participatory workshop built as an average across 18 individual stakeholder responses (Annex E).

\begin{tabular}{|c|c|c|c|c|c|c|}
\hline \multirow[b]{2}{*}{ Policy alternatives } & \multicolumn{3}{|c|}{$\begin{array}{c}\text { Ranking I } \\
\text { (based on equal weights) }\end{array}$} & \multicolumn{3}{|c|}{$\begin{array}{c}\text { Ranking II } \\
\text { (based on stakeholder weights) }\end{array}$} \\
\hline & Rank & Sum & Average & Rank & Sum & Average \\
\hline A. Promotion of marketing strategies & 1. & 7.412 & 0.674 & 1. & 5.406 & 0.491 \\
\hline B. Ecolabelling & 3. & 7.161 & 0.651 & 2. & 5.197 & 0.472 \\
\hline C. Promotion of wine tourism & 2. & 7.163 & 0.651 & 3. & 5.194 & 0.472 \\
\hline D. Payments for ecosystem services & 4. & 6.495 & 0.590 & 4. & 4.738 & 0.431 \\
\hline E. UNESCO Cultural World Heritage & 6. & 6.246 & 0.568 & 5. & 4.661 & 0.424 \\
\hline $\begin{array}{l}\text { F. Awareness raising for ecosystem services } \\
\text { stewardship }\end{array}$ & 7. & 6.162 & 0.560 & 6. & 4.508 & 0.410 \\
\hline $\begin{array}{l}\text { G. Common Agricultural Policy (CAP) } \\
\text { subsidies }\end{array}$ & 5. & 6.328 & 0.575 & 7. & 4.427 & 0.402 \\
\hline H. Tax reduction for wine farmers & 8. & 5.330 & 0.485 & 8. & 3.665 & 0.333 \\
\hline Status Quo & 9. & 3.250 & 0.295 & 9. & 5.406 & 0.491 \\
\hline
\end{tabular}


Important note: This is the author's post-print version of a research paper that was accepted for publication in the journal Ecosystem Services (Elsevier). Therefore, it underwent full peer review but has not been through the copyediting, typesetting, pagination and proofreading process, which may lead to differences between this version and the published version: Langemeyer J., Baraibar S., Palomo I., Gómez-Baggethun E. (2018). Participatory Multi-Criteria Decision Aid: A way to operationalize ecosystem services. Ecosystem Services: 30 , Part A, 49-60. https://doi.org/10.1016/j.ecoser.2018.01.012 
Important note: This is the author's post-print version of a research paper that was accepted for publication in the journal Ecosystem Services (Elsevier). Therefore, it underwent full peer review but has not been through the copyediting, typesetting, pagination and proofreading process, which may lead to differences between this version and the published version: Langemeyer J., Baraibar S., Palomo I., Gómez-Baggethun E. (2018). Participatory Multi-Criteria Decision Aid: A way to operationalize ecosystem services. Ecosystem Services: 30 , Part A, 49-60. https://doi.org/10.1016/j.ecoser.2018.01.012

\subsection{Reflection on the evaluation of policy alternatives}

The final discussion aimed at a critical reflection of the evaluation of policies conducted in previous steps. Most importantly, the discussion led to the conclusion that not a single policy alternative was most promising but rather a combination of at least the three highest ranked policy alternatives (A. Promotion of marketing strategies, B. Ecolabelling and C. Promotion of wine tourism).

The final discussion also helped in uncovering that one of the most important barriers for the implementation of policy alternatives is given by lacking leadership and lacking unity within the stakeholder group of traditional winegrowers and the wine growing sector in general. A stronger alliance between winegrowers, wine producers, and local municipalities was assumed to be critical to reverse the decline of ES from traditional vineyards in Doñana.

The discussion further raised the issue of scale as critically determining factor for the implementation of policy alternatives. Although previous European CAP subsidies for vineyard abandonment were seen as the major drivers of the decline in ES, the most important ES provided by traditional vineyards were rather of local (e.g., maintenance of cultural identity) or regional importance (e.g., sedimentation and erosion control). The absence of the agricultural department of the Andalusian government in the process was seen as symptomatic for the disinterest of regional, national, and European scale administrations in the environmental stewardship function that traditional winegrowers are carrying out, for instance, by providing ecological corridors for biodiversity in the buffer zone surrounding the National Park of Doñana.

\subsection{Quality of the participatory MCDA process}

Stakeholder interviews allowed for a final quality control of the MCDA process. Results are structured around three major arguments that Fish et al. (2016) presented for stakeholder participation in IAES:

Normative-based arguments: Stakeholders involved in this process evaluated the participatory MCDA as highly transparent and inclusive (Fig 5), and thus in line with the general principle for a legitimate conflict resolution procedure in fuzzy environments (O’Neill, 2001). Our study shows margin for improvement in the systematic inclusion of stakeholders and an overrepresentation of small-scale winegrowers was recognized.

Process-based arguments: Notwithstanding some remaining skepticism and distrust between stakeholder groups, most stakeholders considered the participatory MCDA process as highly valuable for building trust and facilitating mutual learning across the different stakeholder groups. The 
Important note: This is the author's post-print version of a research paper that was accepted for publication in the journal Ecosystem Services (Elsevier). Therefore, it underwent full peer review but has not been through the copyediting, typesetting, pagination and proofreading process, which may lead to differences between this version and the published version: Langemeyer J., Baraibar S., Palomo I., Gómez-Baggethun E. (2018). Participatory Multi-Criteria Decision Aid: A way to operationalize ecosystem services. Ecosystem Services: 30 , Part A, 49-60. https://doi.org/10.1016/j.ecoser.2018.01.012

inclusion of stakeholders in all steps was perceived to enhance legitimacy and guaranteed strong control for stakeholders during the decision-making process; it even allowed identifying common interests among stakeholder groups that were previously assumed to defend opposing objectives. Yet, a repeated critique by interview partners was about the lack of consideration and alignment of previous and in parallel ongoing processes.

Outcome-based arguments: Participants stated a large overall satisfaction with the process and described its outcomes as highly useful with regard to the general objective, to coin a strategy that would maintain the traditional vineyards of Doñana and to sustain local stewardship of ES. In retrospect it can be argued that researchers in this study basically functioned as facilitators or catalysts to include local knowledge in the ES assessment. The ES concept was thereby perceived as a bridging tool for communication and expression of pluralistic objectives across different stakeholder groups.

All the relevant stakeholders were represented

There was a high level of interaction among the represented stakeholders

The process was transparent

I trust the people involved

The process was inclusive and provided opportunities to get involved

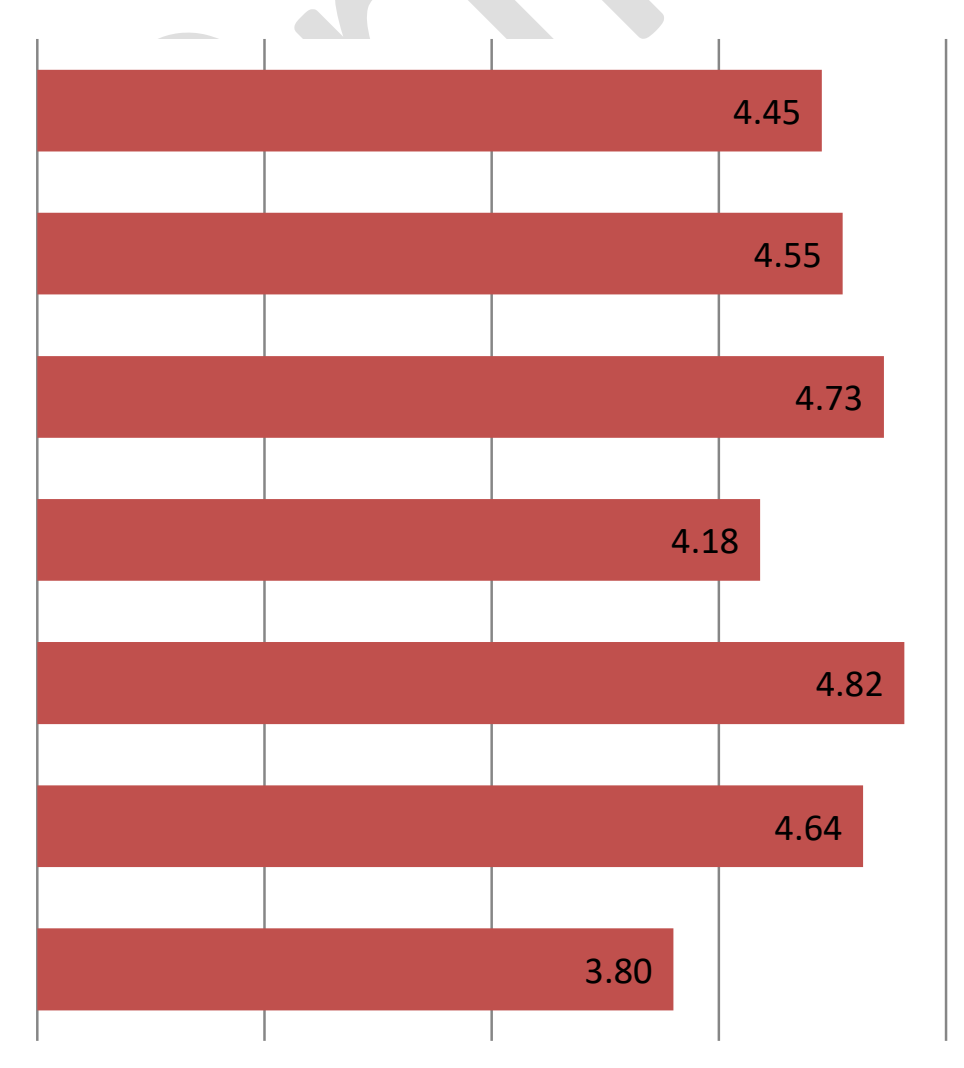

The process was aligned with other ongoing processes

There was good facilitation

Figure 5: Process quality control of the participatory MCDA conducted in the case of Doñana's traditional vineyards.

Evaluation of the stakeholder process. Based on 11 anonymous interviews to participants of the stakeholder workshops using a 5-point Likert scale ranking, where 1 means not at all satisfying and 5 means fully satisfying. 
Important note: This is the author's post-print version of a research paper that was accepted for publication in the journal Ecosystem Services (Elsevier). Therefore, it underwent full peer review but has not been through the copyediting, typesetting, pagination and proofreading process, which may lead to differences between this version and the published version: Langemeyer J., Baraibar S., Palomo I., Gómez-Baggethun E. (2018). Participatory Multi-Criteria Decision Aid: A way to operationalize ecosystem services. Ecosystem Services: 30 , Part A, 49-60. https://doi.org/10.1016/j.ecoser.2018.01.012 
Important note: This is the author's post-print version of a research paper that was accepted for publication in the journal Ecosystem Services (Elsevier). Therefore, it underwent full peer review but has not been through the copyediting, typesetting, pagination and proofreading process, which may lead to differences between this version and the published version: Langemeyer J., Baraibar S., Palomo I., Gómez-Baggethun E. (2018). Participatory Multi-Criteria Decision Aid: A way to operationalize ecosystem services. Ecosystem Services: 30, Part A, 49-60. https://doi.org/10.1016/j.ecoser.2018.01.012

392

\section{DISCUSSION}

Our study aimed at a rigorous inclusion of stakeholders' knowledge and objectives within an IAES in real world decision making. In the following, we lay out the strengths and weaknesses and lessons learned from applying the participatory MCDA to conduct an IAES in the case study of traditional vineyards in Doñana.

\subsection{Representation of multiple stakeholder objectives}

The lack of attention paid to problem structuring in the environmental MCDA (Allain et al., 2017) constitutes a critical issue for the legitimacy of IAES. We argue that a participatory approach to the problem structuring as conducted in the Doñana case study can add legitimacy to IAES. Our study confirms previous studies (e.g., Cork \& Proctor, 2005; Fürst et al., 2013) that addressed the importance and practicality of deliberative approaches to define policy alternatives as well as the importance of selection of evaluation criteria with regard to stakeholder objectives. The criteria selection has a fundamental influence on the outcomes of MCDA, which makes the common praxis of expert and data availability driven selection of ES (e.g., Langemeyer et al., 2016) highly questionable. The participatory selection of ES as evaluation criteria helps steering an IAES to the most relevant stakeholder objectives it needs to focus on and can thereby add legitimacy to decision making.

In this study, we relied on a survey that considered a wide range of stakeholders and their objectives. Predictably, the production of grapes, wine, and vinegar, which traditionally is one of the main economic activities in the area, was perceived as the most important ES. Yet, Doñana's vineyards are rarely profitable from a purely market viewpoint, and their persistence can only be explained by strong cultural ties to the land and the activity (Polonio et al., 2005). The stakeholder driven approach of ES prioritization allowed us to account for less tangible "relational values" (Chan et al., 2016), which local inhabitants assign to traditional vineyards and that have led to the selection of maintenance of cultural identity among the evaluation criteria. An influential global analysis has stressed in this context that societies become less dependent on the local provisioning and regulating ES in the course of their economic development; at the same time, their dependency on cultural ES increases (Guo et al., 2010). They are also increasingly recognized for their economic importance, especially in relation to tourism activities (Martín-López et al., 2009) and their loss is generally irreversible in short- to medium-term (Ojeda, 1997). While qualitative approaches to value cultural ES, e.g., based on social media data, are still in their infancy (Tenerelli et al., 2016), participatory assessments of ES, including interviews, surveys, and focal groups, are key to integrate less tangible cultural ES into decision making. 
Important note: This is the author's post-print version of a research paper that was accepted for publication in the journal Ecosystem Services (Elsevier). Therefore, it underwent full peer review but has not been through the copyediting, typesetting, pagination and proofreading process, which may lead to differences between this version and the published version: Langemeyer J., Baraibar S., Palomo I., Gómez-Baggethun E. (2018). Participatory Multi-Criteria Decision Aid: A way to operationalize ecosystem services. Ecosystem Services: 30, Part A, 49-60. https://doi.org/10.1016/j.ecoser.2018.01.012

In addition, and as shown by our study, participatory approaches to ES assessments can also support the prioritization of regulating and supporting services, especially when evidence and biophysical data on ES are lacking (Fish et al., 2016), which is still a common obstacle for IAES conducted in real world decision making. For example, a recent study had shown for the National Park of Doñana that land-use changes in traditional vineyards have most likely increased land erosion and enhanced marsh siltation (Gaitán-Cremaschi et al., 2017). Although the scientific evidence base remained thin, stakeholders considered sedimentation and erosion control as an important evaluation criterion; similarly, they selected the provision of ecological corridors for biodiversity.

We also assume the recognition and integration of non-ES objectives expressed by local stakeholders, during the participatory MCDA process, as an important condition for a successful IAES. Stagnant grape prices, lack of generational turnover in the vineyard sector, and CAP subsidies for abandoning and uprooting have been identified as major drivers for the loss of traditional vineyards in Doñana (Gaitán-Cremaschi et al., 2017). In response, stakeholders assumed employment and impact on wine sales needed to be considered in the IAES. ES do not necessarily capture all objectives that stakeholders hold and a decision-making process might lose its relevance and legitimacy without the flexibility to integrate non-ES criteria.

\subsection{Simple evaluation approaches for complex solutions}

Our study took place in a context with relatively few formal data on the ES selected as evaluation criteria. Inspired by Koschke et al. (2012), we fully relied on stakeholder knowledge in criteria performance scoring to evaluate the different policy alternatives. Given the complexity of socialecological feedbacks, Saarikoski et al. (2016) underlined that uncertainties and even conflicts about formal data are common in environmental decision making based on an IAES. At least for Doñana, local stakeholders were assumed to have the largest expertise to evaluate how different policy alternatives would affect the provision of ES and the results of participatory criteria scoring were shared and fully accepted by all stakeholders involved in the participatory MCDA process. The (mis)match of the scoring of criteria between four separate split-up groups thereby indicated higher and lower uncertainties among the stakeholders about the performance of specific criteria.

The influence of stakeholder weights on the evaluation of policy alternatives has been relatively low. This might be explained by the participatory selection of evaluation criteria. We also assume this to explain the (unexpectedly) low standard deviation of weights or, said differently, the wide agreement among stakeholders regarding the ES that they assumed important. Future applications of the 
Important note: This is the author's post-print version of a research paper that was accepted for publication in the journal Ecosystem Services (Elsevier). Therefore, it underwent full peer review but has not been through the copyediting, typesetting, pagination and proofreading process, which may lead to differences between this version and the published version: Langemeyer J., Baraibar S., Palomo I., Gómez-Baggethun E. (2018). Participatory Multi-Criteria Decision Aid: A way to operationalize ecosystem services. Ecosystem Services: 30, Part A, 49-60. https://doi.org/10.1016/j.ecoser.2018.01.012

participatory MCDA might provide evidence if a participatory selection of evaluation criteria can partly substitute a sophisticated weighting approach and vice-versa.

Environmental decision making, such as in the Doñana case study, can generally be assumed to embed trade-offs between ES (Turkelboom et al. forthcoming), that means a strong delivery of one ES diminishes another ES. The WLA model applied in this study has often been considered "reductionist" when trade-offs are at stake due to the lack of consideration of incommensurability relationships (Munda, 2008); this means that, in WLA, bad performance in one criterion can be compensated by good performance in another criterion (Langemeyer et al., 2016; Saarikoski et al., 2016). Despite this clear limitation, in the Doñana case study, a WLA model has been preferred over more sophisticated but also more complex mathematical approaches, such as NAIADE or ELECTRE II, for its intuitive mathematical procedure. Where other models are often perceived as "black boxes" the mathematical model underlying WLA widely guaranteed transparency and comprehensiveness during the decisionmaking process. We assume that theoretical drawbacks of the WLA approach were widely balanced out using the evaluation rankings (Fig. 3) not as an end-point but as a starting point for the final reflection (cf. Stirling, 2006; Saarikoski et al., 2016).

Land-use changes are generally assumed to be caused by a combination of drivers (Plieninger et al., 2016). To reverse the decline of ES resulting from land-use changes, a combination of policy alternatives has been shown to be needed in response. While the participatory MCDA clearly stressed that the status quo only accelerates ongoing losses of ES in Doñana (Zorrilla-Miras et al., 2014; Palomo et al., 2011), the final discussion showed that there is no single policy alternative that would alter the loss of ES from Doñana's traditional vineyards. Where the classical MCDA approaches often culminate in the simplistic selection of a single policy alternative ( $c f$. Alain et al., 2017), the simple WLA approach applied in this study has helped to operationalize an IAES that opens up a debate about hybrid solutions, for instance, a combination of policy alternatives including the A. Promotion of marketing strategies, B. Ecolabelling, and C. Promotion of wine tourism.

\subsection{ES stewardship through local stakeholder empowerment}

The participatory MCDA of this study created awareness about the need of local solutions to the overarching problem of declining ES from Doñana's traditional vineyards. The shift toward land uses that provide higher market value is a major driver of land-use change in ecosystems across the world (Lambin et al., 2010). In Europe, EU policies incentivized short term, private, monetary benefits at the expense of reduced ES (i.e., De Groot, 2006). Local stakeholders in Doñana have thereby lost 
Important note: This is the author's post-print version of a research paper that was accepted for publication in the journal Ecosystem Services (Elsevier). Therefore, it underwent full peer review but has not been through the copyediting, typesetting, pagination and proofreading process, which may lead to differences between this version and the published version: Langemeyer J., Baraibar S., Palomo I., Gómez-Baggethun E. (2018). Participatory Multi-Criteria Decision Aid: A way to operationalize ecosystem services. Ecosystem Services: 30, Part A, 49-60. https://doi.org/10.1016/j.ecoser.2018.01.012

influence in land-use management (Gómez-Baggethun et al., 2012) and feel disempowered toward the regional Andalusian government, the Spanish government, and the EU. Policies relying on these institutions were evaluated as less effective for the purpose of maintaining ES. Yet, the participatory MCDA process of this study has helped to increase the understanding among local stakeholders involved that counteracting the global decline in ES-described by the MEA (2005) and other studies - requires consolidated policies at the local level. The use of the participatory MCDA for IAES counteracted the perception of disempowerment among local stakeholders, as it helped to create awareness for the role of winegrowers as local stewards of multiple highly appreciated ES. The participatory MCDA process allowed for learning and mutual trust building between the local stakeholders, thereby paving the way for consolidated local polices to sustain ES (Ostrom, 2015). We assume that the overrepresentation of small-scale winegrowers - as key stakeholders that are both highly affecting and highly affected by the decisions at stake (Morris et al., 2009) — during the stakeholder workshops helped their empowerment as stewards of ES. We assume the absence of politically or economically more powerful stakeholders, such as national government and industrial farmers, to have facilitated trust building and empowerment of local stakeholders. However, their absence during the process means their interests are not considered, this might hamper the implementation of policy alternatives and might even cause future opposition to them. The participatory MCDA process has also uncovered the lacking union of local stakeholders, which is now identified as the major obstacle in curbing the declining trend of traditional vineyards and enhancing stewardship for ES.

\section{Conclusions}

This study highlights fundamental benefits for environmental decision making related to the integration of stakeholders into IAES. Results reinforce that participation is adding legitimacy (based on the consideration of stakeholder objectives) and valuable information (based on stakeholder knowledge) to decision-making processes, especially but not exclusively, if formal data is scarce and uncertainties are high. Participatory MCDA has shown to be a powerful framework for the inclusion and empowerment of stakeholders within IAES, and, by opening up discussions, capable of evaluating and supporting the consolidation of policies. Finally, and in line with other ongoing research, we argue that legitimate participatory processes that consider the multiple objectives of local stewards and integrate local knowledge and values are most promising in fostering environmental stewardship to secure the resilient supply of ES. 
Important note: This is the author's post-print version of a research paper that was accepted for publication in the journal Ecosystem Services (Elsevier). Therefore, it underwent full peer review but has not been through the copyediting, typesetting, pagination and proofreading process, which may lead to differences between this version and the published version: Langemeyer J., Baraibar S., Palomo I., Gómez-Baggethun E. (2018). Participatory Multi-Criteria Decision Aid: A way to operationalize ecosystem services. Ecosystem Services: 30, Part A, 49-60. https://doi.org/10.1016/j.ecoser.2018.01.012

\section{7}

\section{Acknowledgment}

We especially thank all the participants of the workshops, Ana Villa, and Jesús Mateos and the Fundación Doñana 21 and all others who facilitated our field work. We would also like to thank the reviewers for their detailed and encouraging remarks. This research was funded by European Commission project OpenNESS (FP7-Grant agreement: 308428308428), by a Juan de la Cierva Formación grant from the Spanish Ministry of Economy and Competitiveness to I.P. and by a grant of the talent development program of the Norwegian University of Life Sciences (NMBU) to E.G.B..

\section{References}

1. Allain, S., Plumecocq, G., \& Leenhardt, D. (2017). How Do Multi-criteria Assessments Address Landscape-level Problems? A Review of Studies and Practices. Ecological Economics 136: 282-295.

2. Baraibar, S. (2015). Design of Policy measures to protect ecosystem services from cultural landscapes. A case study in the traditional vineyards of Doñana, Spain., Universitat Autòn. de Barcelona, MSc thesis.

3. Barton, D.N. \& P.A. Harrison (Eds.). Integrated valuation of ecosystem services. Guidelines and experiences. European Commission FP7, 2017. EU FP7 OpenNESS Project Deliverable 33-44.

4. Bernard H.R., (2005). Research methods in anthropology: qualitative and quantitative approaches. Walnut Creek, CA: Altamir Press.

5. Blondel J., Aronson J., Bodiou J.Y., Boeuf G., (2010). Mediterranean Region Biological Diversity in Space and Time. Oxford University Press, 392.

6. Braat L. (2014). Mapping of Ecosystems and Their Services in the EU and Its Member States (MESEU): Synthesis 2012-2014, Alterra-Wagingen. (03 May 2017; https://circabc.europa.eu/webdav/CircaBC/env/ecosystem_assesment/Library/2015\%20MAES \%20Hands\%200n\%20Workshops/MESEU-synthesis\%20report-2012-2014 14012015.pdf)

7. Bryan, B.A., Kandulu, J.M., 2011. Designing a policy mix and sequence for mitigating agricultural non-point source pollution in a water supply catchment. Water Resour. Manag. 25 (3), 875-892.

8. Camps-Calvet, M., Langemeyer, J., Calvet-Mir, L., \& Gómez-Baggethun, E. (2016). Ecosystem services provided by urban gardens in Barcelona, Spain: insights for policy and planning. Environmental Science \& Policy, 62, 14-23.

9. Chan, K. M., Balvanera, P., Benessaiah, K., Chapman, M., Díaz, S., Gómez-Baggethun, E., ... \& Luck, G. W. (2016). Opinion: Why protect nature? Rethinking values and the environment. Proceedings of the National Academy of Sciences, 113(6), 1462-1465.

10. Cork, S.J., Proctor, W. (2005). Implementing a Process for Integration Research : ESs Project, Australia. Journal of Research Practice, 1(2), 1-25.

11. Costanza R., De Groot R.S., Braat L., Kubiszewski I., Fioramonti L., Sutton P., Farber S., Grasso M. (2017). Twenty years of ecosystem services: How far have we come and how far do we still need to go? EcoSer 28A: 1-16. https://doi.org/10.1016/j.ecoser.2017.09.008 
Important note: This is the author's post-print version of a research paper that was accepted for publication in the journal Ecosystem Services (Elsevier). Therefore, it underwent full peer review but has not been through the copyediting, typesetting, pagination and proofreading process, which may lead to differences between this version and the published version: Langemeyer J., Baraibar S., Palomo I., Gómez-Baggethun E. (2018). Participatory Multi-Criteria Decision Aid: A way to operationalize ecosystem services. Ecosystem Services: 30 , Part A, 49-60. https://doi.org/10.1016/j.ecoser.2018.01.012

12. De Groot R.S., Stuip M.A.M., Finlayson C.M., Davidson N. (2006). "Valuing wetlands: guidance for valuing the benefits derived from wetland ecosystem services". Ramsar Technical Report No. 3/CBD Technical Series No. 27.

13. Dick, J., Turkelboom, F., Woods, H., Iniesta-Arandia, I., Primmer, E., Saarela, S.-R., Bezák, P., Mederly, P., Leone, M., Verheyden, W., Kelemen, E., Hauck, J., Andrews, C., Antunes, P., Aszalós, R., Baró, F., Barton, D.N., Berry, P., Bugter, R., Carvalho, L., Czúcz, B., Dunford, R., Blanco, G.G., Geamănă, N., Giucă, R., Grizzetti, B., Izakovičová, Z., Kertész, M., Kopperoinen, L., Langemeyer, J., Lapola, D.M., Liquete, C., Luque, S., Pastur, G.M., MartinLopez, B., Mukhopadhyay, R., Niemela, J., Odee, D., Peri, P.L., Pinho, P., Patrício-Roberto, G.B., Preda, E., Priess, J., Röckmann, C., Santos, R., Silaghi, D., Smith, R., Vădineanu, A., van der Wal, J.T., Arany, I., Badea, O., Bela, G., Boros, E., Bucur, M., Blumentrath, S., Calvache, M., Carmen, E., Clemente, P., Fernandes, J., Ferraz, D., Fongar, C., GarcíaLlorente, M., Gómez-Baggethun, E., Gundersen, V., Haavardsholm, O., Kalóczkai, Á., Khalalwe, T., Kiss, G., Köhler, B., Lazányi, O., Lellei-Kovács, E., Lichungu, R., Lindhjem, H., Magare, C., Mustajoki, J., Ndege, C., Nowell, M., Girona, S.N., Ochieng, J., Often, A., Palomo, I., Pataki, G., Reinvang, R., Rusch, G., Saarikoski, H., Smith, A., Massoni, E.S., Stange, E., Traaholt, N.V., Vári, Á., Verweij, P., Vikström, S., Yli-Pelkonen, V., Zulian, G., 2017. Stakeholders' perspectives on the operationalisation of the ecosystem service concept: Results from 27 case studies. Ecosyst. Serv. https://doi.org/10.1016/j.ecoser.2017.09.015

14. Dunford, R., Harrison, P., Smith, A., Dick, J., Barton, D.N., Martin-Lopez, B., Kelemen, E., Jacobs, S., Saarikoski, H., Turkelboom, F., Verheyden, W., Hauck, J., Antunes, P., Aszalós, R., Badea, O., Baró, F., Berry, P., Carvalho, L., Conte, G., Czúcz, B., Garcia Blanco, G., Howard, D., Giuca, R., Gomez-Baggethun, E., Grizetti, B., Izakovicova, Z., Kopperoinen, L., Langemeyer, J., Luque, S., Lapola, D.M., Martinez-Pastur, G., Mukhopadhyay, R., Roy, S.B., Niemelä, J., Norton, L., Ochieng, J., Odee, D., Palomo, I., Pinho, P., Priess, J., Rusch, G., Saarela, S.-R., Santos, R., van der Wal, J.T., Vadineanu, A., Vári, Á., Woods, H., YliPelkonen, V., 2017. Integrating methods for ecosystem service assessment: Experiences from real world situations. Ecosyst. Serv. doi:10.1016/j.ecoser.2017.10.014

15. Fernández-Delgado C., (2005). Conservation management of a European natural area: Doñana national park, Spain. In: Groom, M.J., Meffe, G.K., Carroll, C.R., (Eds.), Principles of Conservation Biology. Sinauer Associates Inc., USA: Massachusetts, 536-543.

16. Fish, R., Saratsi, E., Reed, M., \& Keune, H. (2016). Stakeholder participation in ecosystem service decision making. In Potschin et al. Routledge Handbook of Ecosystem Services. Routlegde: 256-270.

17. Foley, J. A., DeFries, R., Asner, G. P., Barford, C., Bonan, G., Carpenter, S. R., ... \& Helkowski, J. H. (2005). Global consequences of land use. Science, 309(5734), 570-574.

18. Funtowicz, S. O., \& Ravetz, J. R. (1994). The worth of a songbird: ecological economics as a post-normal science. Ecological Economics, 10(3), 197-207.

19. Fürst, C., Frank, S., Witt, A., Koschke, L., \& Makeschin, F. (2013). Assessment of the effects of forest land use strategies on the provision of ecosystem services at regional scale. Journal of environmental management, 127, S96-S116.

20. Gaitán-Cremaschi, D., Palomo, I., Molina, S. B., De Groot, R., \& Gómez-Baggethun, E. (2017). Applicability of economic instruments for protecting ecosystem services from cultural agrarian landscapes in Doñana, SW Spain. Land Use Policy, 61, 185-195. 
Important note: This is the author's post-print version of a research paper that was accepted for publication in the journal Ecosystem Services (Elsevier). Therefore, it underwent full peer review but has not been through the copyediting, typesetting, pagination and proofreading process, which may lead to differences between this version and the published version: Langemeyer J., Baraibar S., Palomo I., Gómez-Baggethun E. (2018). Participatory Multi-Criteria Decision Aid: A way to operationalize ecosystem services. Ecosystem Services: 30, Part A, 49-60. https://doi.org/10.1016/j.ecoser.2018.01.012

21. Gimmi U., Lachat T., Bürgi M., (2011). Reconstructing the collapse of wetland networks in the Swiss lowlands 1850-2000. Landscape Ecol, 26:1071-1083.

22. Gómez-Baggethun, E., Barton, D., Berry, P., Dunford, R., Harrison, P. 2016. Concepts and methods in ecosystem services valuation. In: Potschin, M., Haines-Young, R., Fish, R. and Turner, R.K. (eds.) Routledge Handbook of Ecosystem Services. Routledge, London and New York, pp. 99-111.

23. Gómez-Baggethun, E., Mingorría, S., Reyes-García, V., Calvet, L., Montes, C. 2010. Traditional ecological knowledge trends in the transition to a market economy: Empirical study in Doñana natural areas. Conservation Biology 24:721-729.

24. Gómez-Baggethun E., Martín-López B., Lomas P., Zorrilla-Miras P., \& Montes, C. (2011). Evolution of ecosystem services in a Mediterranean cultural landscape: Doñana case study, Spain (1956-2006). InTech Press, 27-46.

25. Gómez-Baggethun E., Reyes-García V., Olsson P., \& Montes C. (2012). Traditional ecological knowledge and community resilience to environmental extremes. A case study in Doñana, SW Spain. Global Environmental Change, 22:640-650.

26. Guerry, A. D., Polasky, S., Lubchenco, J., Chaplin-Kramer, R., Daily, G. C., Griffin, R., ... \& Feldman, M. W. (2015). Natural capital and ecosystem services informing decisions: From promise to practice. Proceedings of the National Academy of Sciences, 112(24), 7348-7355.

27. Guo Z., Zhang L., \& Li Y. (2010). Increased dependence of humans on ecosystem services and biodiversity. PLoS ONE, 5(11):e13113.

28. Haase D, Larondelle N, McPhearson T, Schwarz N, Hamstead Z, Kremer P, Langemeyer J, Elmqvist $\mathrm{T}$ et al. (2014): Quantitative review of urban ecosystem services assessment: Concepts, models and implementation. AMBIO, 43:413-433.

29. Haines-Young, R. and Potschin, M. (2013): Common International Classification of Ecosystem Services (CICES): Consultation on Version 4, August-December 2012. EEA Framework Contract No EEA/IEA/09/003

30. Jacobs, S., Dendoncker, N., Martín-López, B., Barton, D. N., Gomez-Baggethun, E., Boeraeve, F., ... \& Pipart, N. (2016). A new valuation school: Integrating diverse values of nature in resource and land use decisions. Ecosystem Services, 22, 213-220.

31. Karjalainen, T.P., Marttunen, M., Sarkki, S., Rytkönen, A.-M. (2013). Integrating ESs into environmental impact assessment: An analytic-deliberative approach. Environmental Impact Assessment Review, 40:54-64.

32. Koschke, L., Fürst, C., Frank, S., Makeschin, F., 2012. A multi-criteria approach for an integrated land cover based assessment of ecosystem services provision. Ecological Indicators $21,54 \mathrm{e} 66$.

33. Lambin E. F., \& Meyfroidt P. (2010). Land use transitions: Socio-ecological feedback versus socio-economic change. Land use policy, 27(2):108-118.

34. Langemeyer, J., Gómez-Baggethun, E., Haase, D., Scheuer, S., \& Elmqvist, T. (2016). Bridging the gap between ecosystem service assessments and land-use planning through Multi-Criteria Decision Analysis (MCDA). Environmental Science \& Policy, 62, 45-56.

35. Manson S.M, Nicholas R., Kristen C.N, R.F. (2014). Modeling the effect of social networks on adoption of multifunctional agriculture. 
Important note: This is the author's post-print version of a research paper that was accepted for publication in the journal Ecosystem Services (Elsevier). Therefore, it underwent full peer review but has not been through the copyediting, typesetting, pagination and proofreading process, which may lead to differences between this version and the published version: Langemeyer J., Baraibar S., Palomo I., Gómez-Baggethun E. (2018). Participatory Multi-Criteria Decision Aid: A way to operationalize ecosystem services. Ecosystem Services: 30 , Part A, 49-60. https://doi.org/10.1016/j.ecoser.2018.01.012

36. Martín López B., Gómez-Baggethun E., Lomas P.L., Montes C. (2009). Effects of spatial and temporal scales on cultural services valuation. Journal of Environmental Management, 10501059.

37. Martín-López B., García-Llorente M., Palomo I., Montes C. (2011). The conservation against development paradigm in protected areas: Valuation of ecosystem services in the Doñana social-ecological system. Ecological Economics, 70:1481-1491.

38. Morris, J., Posthumus, H., Hess, T., Gowing, D., Rouquette, J. (2009). Watery land: the management of lowland floodplains in England. In Winter \& Lobley (eds) What is Land for? Earthscan, London.

39. Munda, G. (2008). Social multi-criteria evaluation for a sustainable economy (p. 210). Berlin: Springer.

40. Ojeda-Rivera, J. F. (1990). Doñana cultural landscape. In Doñana: la naturaleza en España 1825.

41. O'Neill, J. (2001). Representing people, representing nature, representing the world. Environment and Planning C: Government and Policy, 19(4), 483-500.

42. Ostrom, E. (2015). Governing the commons. Cambridge university press.

43. Palomo, I., Martín-López, B., López-Santiago, C., \& Montes, C. (2011). Participatory scenario planning for protected areas management under the ecosystem services framework: the Doñana social-ecological system in southwestern Spain. Ecology and Society, 16(1).

44. Palomo, I., Martín-López, B., Zorrilla-Miras, P., Del Amo, D. G., \& Montes, C. (2014). Deliberative mapping of ecosystem services within and around Doñana National Park (SW Spain) in relation to land use change. Regional environmental change, 14(1), 237-251.

45. Plieninger, T., Draux, H., Fagerholm, N., Bieling, C., Bürgi, M., Kizos, T., ... \& Verburg, P. H. (2016). The driving forces of landscape change in Europe: A systematic review of the evidence. Land Use Policy, 57, 204-214.

46. Polonio B., Méndez M.A., Lucena B., Cáceres F., Manrique T. (2005). Diagnóstico del sector vitivinícola del marco del Condado de Huelva. Junta de Andalucía, consejería de Agricultura y pesca. Sevilla. (in Spanish)

47. Posner, S. M., McKenzie, E., \& Ricketts, T. H. (2016). Policy impacts of ecosystem services knowledge. Proceedings of the National Academy of Sciences, 113(7), 1760-1765.

48. Radeloff V.C., Stewart S.I., Hawbaker T.J. et al. (2010). Housing growth in and near United States protected areas limits their conservation value. Acad. Sci. 107:940-945.

49. Ruckelshaus, M., McKenzie, E., Tallis, H., Guerry, A., Daily, G., Kareiva, P., ... \& Bernhardt, J. (2015). Notes from the field: lessons learned from using ecosystem service approaches to inform real-world decisions. Ecological Economics, 115, 11-21.

50. Saarikoski, H., Mustajoki, J., Barton, D., Geneletti, D., Langemeyer, J., , Gómez-Baggethun, E., Marttunen, M., Antunes, P., Keune, H., Santos, R. (2016). Multi-criteria decision analysis and cost-benefit analysis: Comparing alternative frameworks for integrated valuation of ecosystem services. Ecosystem Services, 22, 238-249.

51. Saarikoski, H., Primmer, E., Saarela, S.-R., Antunes, P., Aszalós, R., Baró, F., Berry, P., Blanko, G.G., Goméz-Baggethun, E., Carvalho, L., Dick, J., Dunford, R., Hanzu, M., Harrison, P.A., Izakovicova, Z., Kertész, M., Kopperoinen, L., Köhler, B., Langemeyer, J., Lapola, D., Liquete, C., Luque, S., Mederly, P., Niemelä, J., Palomo, I., Pastur, G.M., Peri, P.L., Preda, E., Priess, J.A., Santos, R., Schleyer, C., Turkelboom, F., Vadineanu, A., 
Important note: This is the author's post-print version of a research paper that was accepted for publication in the journal Ecosystem Services (Elsevier). Therefore, it underwent full peer review but has not been through the copyediting, typesetting, pagination and proofreading process, which may lead to differences between this version and the published version: Langemeyer J., Baraibar S., Palomo I., Gómez-Baggethun E. (2018). Participatory Multi-Criteria Decision Aid: A way to operationalize ecosystem services. Ecosystem Services: 30 , Part A, 49-60. https://doi.org/10.1016/j.ecoser.2018.01.012

Verheyden, W., Vikström, S., Young, J., (2017). Institutional challenges in putting ecosystem service knowledge in practice. Ecosyst. Serv. doi:10.1016/j.ecoser.2017.07.019

52. Soy-Massoni E, Langemeyer J, Varga D, Saez M, Pint J, (2016). The importance of ecosystem services in coastal agricultural landscapes: Case study from the Costa Brava, Catalonia. Ecosystem Services, 17, 43-52.

53. Srdjevic, Z., Lakicevic, M., Srdjevic, B. (2013). Approach of decision making based on the analytic hierarchy process for urban landscape management. Environmental management, 51(3):777-85.

54. Stenseke M., (2009). Local participation in cultural landscape maintenance: lessons from Sweden. Land Use Policy, 26:214-223.

55. Stirling, A. 2006. Analysis, participation and power. Justification and closure in participatory multi-criteria analysis. Land Use Policy 23: 95-107.

56. Tenerelli, P., Demšar, U., \& Luque, S. (2016). Crowdsourcing indicators for cultural ecosystem services: a geographically weighted approach for mountain landscapes. Ecological Indicators, 64, 237-248.

57. Turkelboom, F., Leone, M., Jacobs, S., Kelemen, E., García-Llorente, M., Baró, F., Termansen, M., Barton, D.N., Berry, P., Stange, E., Thoonen, M., Kalóczkai, Á., Vadineanu, A., Castro, A.J., Czúcz, B., Röckmann, C., Wurbs, D., Odee, D., Preda, E., GómezBaggethun, E., Rusch, G.M., Pastur, G.M., Palomo, I., Dick, J., Casaer, J., van Dijk, J., Priess, J.A., Langemeyer, J., Mustajoki, J., Kopperoinen, L., Baptist, M.J., Peri, P.L., Mukhopadhyay, R., Aszalós, R., Roy, S.B., Luque, S., Rusch, V., 2017. When we cannot have it all: Ecosystem services trade-offs in the context of spatial planning. Ecosyst. Serv. doi:10.1016/j.ecoser.2017.10.011

58. Turner, R.K. (2016). Ecological Economics and Ecosystem Services. In Potschin et al. Routledge Handbook of Ecosystem Services. Routlegde: 243-256.

59. Uhde, B., Hahn, W. A., Griess, V. C., \& Knoke, T. (2015). Hybrid MCDA methods to integrate multiple ecosystem services in forest management planning: a critical review. Environmental management, 56(2), 373-388.

60. Wittmer, H., Rauschmayer, F., \& Klauer, B. (2006). How to select instruments for the resolution of environmental conflicts? Land Use Policy, 23(1), 1-9.

61. Zaller, J. G., Winter, S., Strauss, P., Querner, P., Kriechbaum, M., Pachinger, B., ... \& Comsa, M. (2015). BiodivERsA project VineDivers: Analysing interlinkages between soil biota and biodiversity-based ecosystem services in vineyards across Europe. In EGU General Assembly Conference Abstracts, 17:7272.

62. Zhang, X., Lu, X., 2010. Multiple criteria evaluation of ecosystem services for the Ruoergai Plateau Marshes in southwest China. Ecol. Econ. 69 (7), 1463-1470.

63. Zia, A., Hirsch, P., Songorwa, A., Mutekanga, D.R., O'Connor, S., McShane, T., Norton, B., 2011. Cross-scale value trade-offs in managing social-ecological systems: the politics of scale in Ruaha national park, Tanzania. Ecol. Soc. 16 (4) .

64. Zorrilla-Miras P., Palomo I., Gómez-Baggethum E., Martín-López B., Lomas P.L., Montes C. (2014). Effects of land-use change on wetland ecosystem services: A case study in the Doñana Natural Areas marshes, SW Spain. Landscape and Urban Planning, 122:16-31 